\title{
JuSTIFICATION FOR 'SCRAPPING THE Sky' A Comprehensive International Review of SKYSCRAPERS/High-Rise BUILDINGS From AN Urban Design Perspective
}

\author{
Tamas Lukovich \\ Institute of Architecture, Faculty of Architecture and Civil Engineering, \\ Szent Istvan University, Budapest, Hungary
}

\begin{abstract}
The magic 'vertical' has always been a spiritually distinctive preoccupation of architecture throughout history. The paper intends to examine, from a series of perspectives, if the high-rise in principle is a good thing. The focus is on urban design implications, however engineering challenges and their design solutions are inseparable aspects of the problematic. It is also to further demystify some ideologies still attached to their widespread application. It concludes that there is a new awareness evolving about high-rise design that is superior to previous approaches.
\end{abstract}

Keywords: changing high-rise definitions, historic height contest, symbolic messages, technical challenges, urban design ideologies and myths, density and form fundamentals, high-rise typology, vertical eco-architecture

\section{INTRODUCTION: THE PHENOMENON, AIMS AND DEFINITIONS}

According to Giedion, our attitude related to the vertical is rooted in our subconscious mind. Among the infinite number of directions and angles, it is separated as a single one that becomes a baseline and reference for comparison. It makes the main endeavour of architecture, i.e. the victory over the force of gravitation, visible. [1] Therefore, building vertical structures has almost always had a spiritual importance and has often been a symbolic event over the history of mankind.

However, it seems that there are still some myths around the justification of high-rise buildings or skyscrapers, even among professional planners and architects. Over the last more than 130 years, while they have been mushrooming, their design and construction have developed a lot and so has our technical knowledge how to build them higher and perhaps more sustainable. But they do not only represent outstanding achievements of a given socio-economic era, they are also multi-layered representations: masculine symbols of power, accomplishment, dominance, aggressive competitiveness, affluence, optimism, pride, prestige, success, glory, arrogance and triumph over natural forces. As Jane Jacobs bluntly put it on their message in her seminal book of 1961 [2]: ‘...’Look what I made!” ... Like a great, visible ego...' In addition, from a spiritual perspective they can be considered the contemporary equivalent of the archaic 'axis mundi', too, that, as pillars, attempt to connect our Earth with Heaven. In the meantime, the tower is also a common symbol of this futile human endeavour (see the Tower of Babel, doomed to failure). 


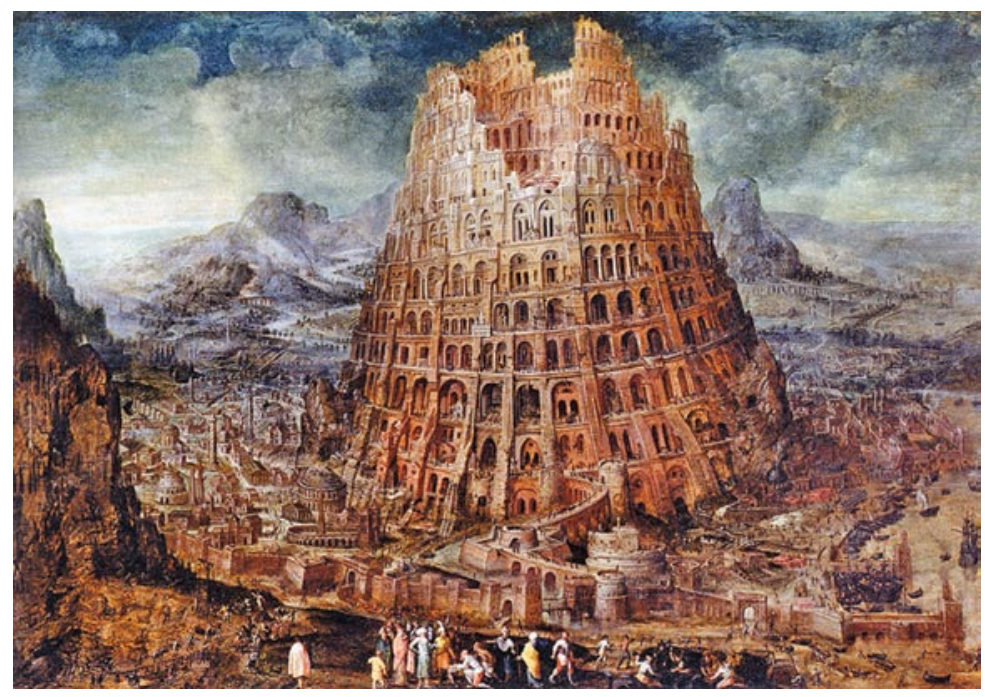

Figure 1. The (Great) Tower of Babel (Ancient Babylon) as imagined by van Valckenborch, around 1600 - symbol of warning man against over-reaching aspirations

Although the skyscraper is a distinctively American invention and they began to go up in the US earlier, it was the Swiss born Le Corbusier (1887-1965, son of a protestant watchmaker family) who conceived the paradigmatic 'City of Towers' concept and was an early and influential advocator of their 'wholesale' application at the urban scale from entire new towns (see the Corbusian Brasilia or the more recent Muong Thong Thani close to Bangkok Airport) to urban reconstruction plans in Europe and North Africa (see Plan Voisin de Paris of 1925, La Ville Contemporaine of 1922, or La Ville Radieuse of 1933). But he was not alone in that: Daniel Burnham (1846-1912) of Chicago also saw the skyscraper as a constituent of a new kind of urbanism early on. However, it is also the US that has provided the world with a strong symbol of related barbarian planning disasters: in St. Luis, after only 17 years of its completion, Pruitt-Igoe award-winning experiment high-rise residential project (designed by Minoru Yamasaki, 1912-1986) was blown up in 1955. (Yamasaki got almost forgotten despite that he also designed the twin towers of the ill-fated World Trade Center in NYC that occupied 14 smaller blocks of the City!) [3, 4] It was barbarian, because it was odd out of local context, i.e. developed without any socio-economic considerations.

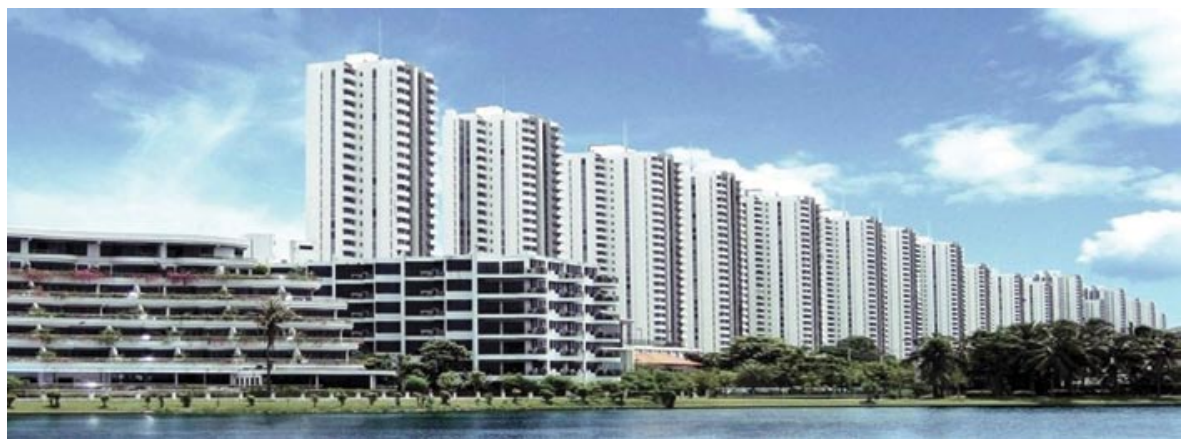

Figure 2. 30 storey apartment blocks along the main boulevard of Muong Thong Thani, one of the largest completely new planned cities, near Bangkok. The project took off in 1989, with a target population of 1 million (bigger than many European historic towns) 




Figure 3. Mock-up of Corbusier's vision: Plan Voisin de Paris (with 18 uniform $213 \mathrm{~m}$ high towers)

High buildings, in general, are clearly the products of a given society, a phenomenon worth looking at in the context of political economy. While early high buildings/structures (e.g. church spires, bell-towers, look out towers) were, by and large public beacons (of religion, government or else), the modern, corporate style (glass and steel) skyscraper is largely a product of private enterprise. [5] It would be too tempting to add that more specifically they are the product of the development of booming laissez-faire capitalism, but developing countries and even some cities of poor communist countries have not avoided the 'high-rise fever' either, but for a slightly different reason. Besides Budapest, this is true even for some relatively small Hungarian country towns of the 1970's (i.e. with inhabitants between 50 and 200 thousand): e.g. Pécs, Miskolc, Szolnok, Veszprém, Debrecen, Gyöngyös, due to narrow minded contesting local leaders with provincial political ambitions, misinterpreting the equation of tall buildings with urban progress. (The one in Pécs even registered in the Guinness Book of Records as the tallest derelict residential building of Central Europe, for almost 20 years!) And before putting any blame on 'careless and barbarian' politicians and/or developers, let us note right at the beginning that the architectural profession has not been 'innocent' either: e.g. just take the high profile Frank Lloyd Wright whose ambition was to build a 1 mile (!) tall skyscraper on Chicago's lakefront, in 1957 already. Many contemporary high-flyer architects ('starchitects'), and their clients (decision makers, including politicians and developers) are obsessed with skyscrapers and desperately want to build iconic buildings. [6]

Now-days, high-rise buildings are present in virtually every climate from the tropics to the desert, in every political system from western democracy to third world dictatorships and developed both by market forces and as state/government projects. Although Shenzhen, Shanghai, Hong Kong, Singapore, Bangkok, Phenjan, Mexico City, Buenos Aires, Sao Paulo, Bogota, Beirut, Dubai, Tokyo, Osaka, Sydney, New York, Chicago, Atlanta, Toronto, Malmö, Madrid, Santa Cruz of Tenerife, Moscow, London, Paris, Milan or Frankfurt do show some local cultural variations on the theme, however, the pure phenomenon (the desire, the endeavour) seems to be universal. It must then originate from generic human nature, whereas both gender and some diabolic characteristics are inherent.

They have no exact definition. 'High-rise buildings' (or 'towers' or 'skyscrapers') are those buildings whose height exceeds a certain limit. This height varies by countries, but conventionally it is between 100-150-(200) $\mathrm{m}$ in local building codes and development control plans, respectively (globally there are more than 6100 buildings over $150 \mathrm{~m}$ altogether now) 
[7], while buildings over $300 \mathrm{~m}$ are called super-high (globally there are 144 of them) and the ones over $600 \mathrm{~m}$ are the mega-high structures in various statistics. [8b] (As a matter of interest, in Hungarian practice the threshold of high-rise is $30 \mathrm{~m}$ measured up to the floor level of the top storey.) However, there are definitions for high-rise buildings from fire safety perspective, too: e.g. 'any structure where height can have a serious impact on evacuation', or 'that extends higher than the maximum reach of available fire-fighting equipment'. (In England, in fact, the height maximum of tall buildings was set for a long while by the length of the fire-fighters' ladder.) [5] But a quite simple, 'common sense' definition also exists that says 'any building which height is multiple of its footprint, and has minimum 20 storeys'.

They are mainly used for commercial (office), hotel, residential or mixed purposes, however there are some examples for other uses, too. Among them there are universities (Moscow, Pittsburgh, Sydney or Budapest), cultural and science palace (Warsaw), public administration (Los Angeles and Toronto) and even some strange combinations (such as the Chicago Temple, marrying church and office tower). [5] They are typically (but not exclusively) steel or composite steel-concrete frame structures, the facades of which are made of curtain walls (not load-bearing walls). From a structural engineering perspective, they are such vertical cantilevers whose standard lateral (wind and earthquake) load is bigger than their own weight ('dead load') and their functional ('live') load. Thus, the wind load becomes the governing factor in structural design, especially in the super-tall range.

The actual local relevance of this study is the new, $120 \mathrm{~m}$ high-rise headquarters of the national oil (public) company (Mol), being developed in my hometown, after decades of periodical debates on metropolitan high-rise policy, on a prominent Buda site along the river Danube. The aims of the paper are to demystify some sustaining corporate architectural and planning ideologies behind their justification and to provide a comprehensive review of relevant issues, including the state-of-the-art and future trends, from an urban design perspective. But the topic is so elusive and many sided that one must be selective (both with the issues involved and the examples cited) - it is impossible to assemble an exhaustive review in a limited paper (a monograph/book would be the appropriate means for that).

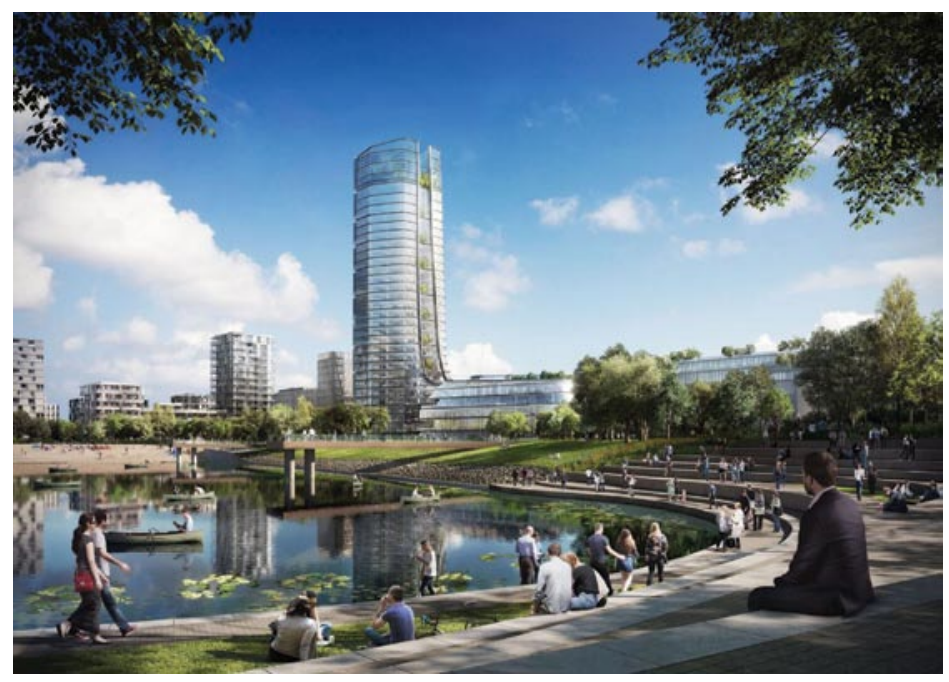

Figure 4. The MOL Campus in South Buda by Foster \& Partners (local partner: the Finta Studio), scheduled for 2021 - the $120 \mathrm{~m}$ high free-standing office tower (Budapest's first real 'skyscraper'), as a non-thematic feature in green surrounding follows the Corbusian legacy and will accommodate a workforce of approx. 2500 
The prime (direct) sources of information for my research were my earlier trips (site visits) to a number of American, European, Asian and Australian metropolises and the secondary (mediated) one was the review of relevant professional literature (both printed and online). Although there is a wealth of information in the subject, there seems to be a gap in such kind of comprehensive review in both the Hungarian and the Anglo-Saxon literature. (In New York City, there is even a Skyscraper Museum, however, it rather focuses on their local development.)

\section{TOWERS AND HIGH-RISE BUILDINGS/STRUCTURES IN HISTORY}

Early on, towers were primarily sacred symbols before the coming of the secular state (e.g. Mesopotamian ziggurats, Buddhist stupas, Hindu gopuras, Chinese pagodas, ancient obelisks, Christian church spires, domes and bell-towers, Muslim minarets), but some came about with practical functions, such as clock-towers, military towers, fire-watchtowers, defensive residential towers and lighting towers to assist navigation. Later, secular towers of public buildings (town halls, post offices, railway stations and campuses of zoos, world expos or universities), besides their symbolic importance (i.e. the representation of common identity and the wealth of a particular community and/or the link between motherland and its far-away colonies), served practical purposes, as well (e.g. orientation - increased legibility of growing towns and campuses, communication, reminders of time and/or look-out points). Besides, largely unconsciously, they have also been phallic symbols right from the beginning: just take Norman Foster's Swiss Re Tower (the 'Cucumber') in London as one of the most apparent examples. $[6,8,9]$

The highest structure of Ancient Times was the Pyramid of Kheops at Gizah, Egypt (146 m), built in the $26^{\text {th }}$ century B.C. (Together with the nearby other pyramids, they were mentioned among the Seven Wonders of Ancient World.) It had not been exceeded for thousands of years. But ten storey residential buildings were not rare in Ancient Rome (several emperors tried to restrict their height), and there were some seven storey residential buildings even in some larger provincial towns, too (with shops at the ground floor, the lower floors with well-to-do families and the upper floors for poorer people).

In the skyline of some significant medieval Christian cities, there appeared some astoundingly tall residential towers (or tower-houses), build by affluent people or by group of families for defence. ('Tower associations' in Florence brought together a large number of people who shared such facilities.) They were the characteristic of cities in Central and Northern Italy, in Southern France and in Central and Southern Germany. In Bologna, Italy, at one stage there were $80-100$ of such towers, the highest being over $97 \mathrm{~m}$. Certainly, their height was an obvious element of the contest. Thus, in Bologna, Rome and Florence, resolutions were made in the $13^{\text {th }}$ century already, to control them, including their maximum height (no tower was to be higher than the Town Hall), visually expressing social and political order on the skyline. Many of them were even brought down as a result, to avoid the undermining of central (communal) authority. (There were, however some exceptions, such as Perugia.) [5]

In medieval Cairo even roof gardens were created on the top of, in some cases, 14 storey buildings. In $17^{\text {th }}$ century in the walled city of Edinburgh, due to the shortage of building sites, there were some 11-14 storey buildings, too. In Shibam, Yemen, the world's highest (UNESCO listed) traditional mud-brick buildings are still in use, some reaching $30 \mathrm{~m}$ (10-11 floors). 

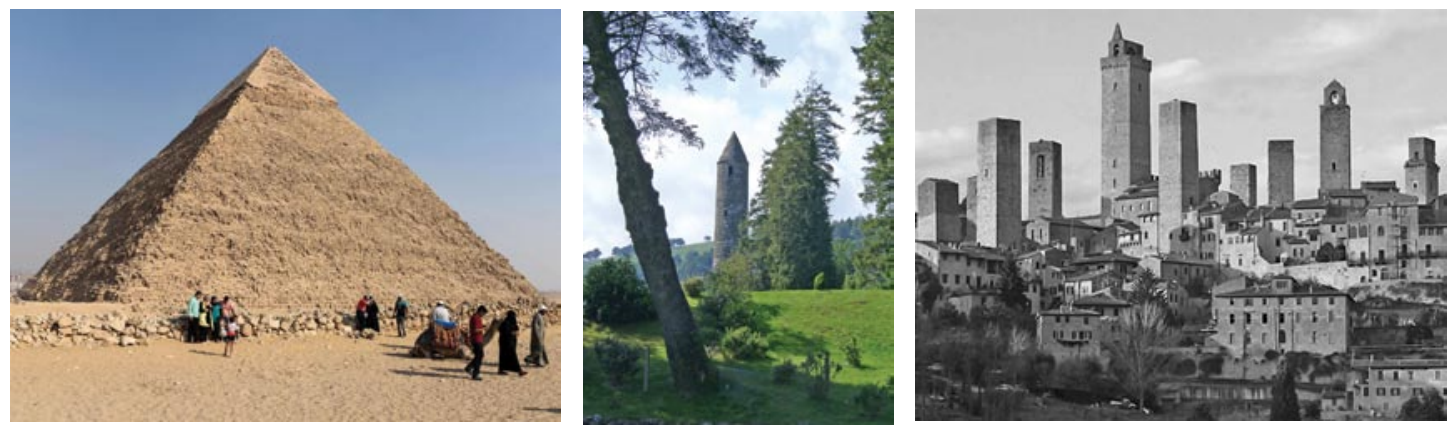

Figure 5. Kheops' Pyramid, (Gizah), Celtic living tower (Ireland), San Gimignano's medieval residential towers (Tuscany) and mud-brick 'high-rise' in Yemen

The engineering revolution of the $19^{\text {th }}$ century provided both the ambition and the opportunity to construct great and tall structures to herald the spectacular advances in metal technology. Most of these project ideas (built and planned) were mainly connected with international expositions. (The winner was France with the $300 \mathrm{~m}$ high Eiffel Tower.) A notable exception was, as it started, a synagogue of Turin with a square dome and spire (the colossal structure reached $167.5 \mathrm{~m}$, done by traditional masonry - in fact, Mole Antonelliana, a museum now, is the tallest masonry structure of the world). [5]

Certainly, a variety of new edifices have appeared on cities' skyline after the industrial revolution: chimney stacks, water tanks, cooling towers, mills, mining/drilling towers, gastanks, silos, communication and transmission towers (basically the hardware of industrial processes), look-out structures and other landmarks. (Kevin Lynch would have also added old missile silos to the list that can be regarded as 'skyscrapers upside down'.) [10]

\section{A SHORT HISTORY OF MODERN SKYSCRAPERS}

In fact, the term skyscraper is only a fanciful word for communication with the public. (In some languages, e.g. in Russian or in Hungarian, literally the term 'cloud-scraper' is used. But even in English, occasionally the term 'sky-rise' has also been used in marketing.) It was first used mainly for office buildings and its meaning has changed substantially over time: in the 1890's a building of ten storeys qualified as a skyscraper, while today it is rarely used for buildings having less than fifty floors. [11]

The first building of cast iron frame was built in 1797 in Shrewsbury, England. It is often referred to as the 'grandfather of skyscrapers'. In 1848, James Bogardus had patented a structural system with cast-iron columns and beams in New York. It was used for the next thirty+ years in American buildings. However, up to the mid-19 $9^{\text {th }}$ century, buildings higher than six storeys were rare, due to the practical difficulties of vertical transportation via staircases and that of water supply.

The construction and comfortable operation of high-rise office towers were made possible by two technical inventions towards the second part of the $19^{\text {th }}$ century: the high-tensile and versatile structural steel-frame, and the safety lift (elevator). 
Steel frames, first developed for bridge building [11], gradually replaced heavy and thick load-bearing walls and the subsequently applied but weaker cast iron. (The world's tallest loadbearing brick building ever constructed - but supported by hidden steel framework - is the 16storey Monadnock Building by Burnham \& Root in Chicago, completed in 1889, with $1.8 \mathrm{~m}$ thick walls at the base. The complex itself represents the shift from load-bearing construction to skeleton-frame construction.) The safety elevator was invented by and first applied in 1853 by Elisha Graves Otis (1811-1861). Later, a third invention, the air conditioning has also contributed to the more widespread application of this building form on all climates. But let us keep in mind that all these great technological developments occurred in the context of a booming US economy, including mass production.

In fact, the transition of steel from merely strengthening masonry to carrying load of the floors, was the most significant step in the history of architecture since Roman times. With it, architecture gained a new dimension. [12] By many, Louis Sullivan (1856-1924) of Chicago is considered the 'father of skyscrapers', however, several architects before him or parallel with him had designed such buildings in the 1870's and 1880's in Chicago and New York. Only taking Chicago (the very cradle of skyscrapers, which was years ahead of N.Y. in the highrise construction boom), there were William Le Baron Jenney (1832-1907), Dankmar Adler (1844-1900) or Daniel Burnham. Besides economic prosperity, the reason behind Chicago's pioneering in the high-rise boom was the devastating fire in 1875, which provided opportunity for developers to rebuild a major part of the Centre (It must not be a pure accident either that 1 May 1886, the 'Haymarket affair' commenced in Chicago during the construction boom era, with a general strike for the eight-hour workday. The workers' demonstration, obviously including many construction labourers, ended up in bloodshed, and the date has later been selected for the commemorative International Labour's Day.) A third city, where most early skyscrapers emerged was the Australian Melbourne between 1888 and 1891, due to the land boom triggered by the Victorian gold rush.

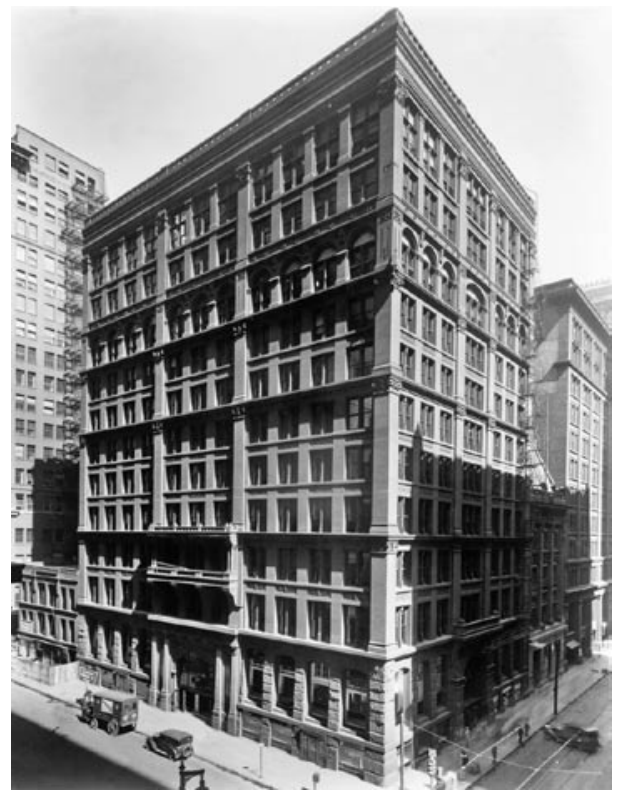

Figure 6. The first modern office building, the Home Insurance Building (1885) in Chicago (it was demolished in 1931 to give way to a new office building on the site)
Now, let us have a quick 'first's' category overview. The first skyscraper of (partially) steelframe structure was the Home Insurance Building in Chicago, opened in 1885 (it was $42 \mathrm{~m}$ tall with 10 storeys only), designed by William Le Baron Jenney. A larger part of the building's weight was carried by iron and steel frames (steel was used on the upper floors) but still with stone facades. [7] Then, it was John Root who completely freed early skyscrapers from masonry building elements, the first being his Rand-McNally Building in 1890. With his associate Daniel Burnham, they built 30 major high-rise buildings in Downtown Chicago. Soon, Charles Louis Strobel introduced the standardisation of steel structural elements (beams and pillars). Furthermore, one of the first skyscrapers using light curtain walls was the Tacoma Building by Holabird and Roche in 1889, also in Chicago. [7] (However, the very first glass curtain walled building, although 5 storey high only, was the Oriel Chambers earlier in Liverpool,. with decorative stone mullions.) [13]

The first residential skyscraper was the Ritz Tower in New York City, designed by Emery Roth, 
and built in 1926 for apartments with hotel service on 41 storeys (165 m high). By the early 1930's, New York had 150 of them. It rapidly became a prototype of a new urban lifestyle and the model was exported to other cities and continents: e.g. in 1934, the $64 \mathrm{~m}$ high, 22 storey Park Hotel was built in Shanghai, designed in art deco style by the Hungarian Laszlo Hudec (it was the tallest building of its time in the Far East till 1958), or in 1934 in Buenos Aires, the 33 storey Kavanagh residential tower was built, also in art deco manner. [12] It was the tallest building in Latin America and the tallest one in the world made of reinforced concrete. (The first one ever built of reinforced concrete, however, was the Ingalls Building in Cincinnati in 1903.) [7] This latter title (precisely, the tallest lightweight concrete building) was taken over in 1967 by Sydney's 50 storey and $170 \mathrm{~m}$ high circular Australia Square Tower (for offices, with a revolving restaurant on the $47^{\text {th }}$ floor and an observation deck on the $48^{\text {th }}$ ) by the Austrian born local architect Harry Seidler and Pier Luigi Nervi. (It was Sydney's tallest skyscraper till 1976, but it remains a landmark building of the metropolis.) In 1977, the Renaissance Center of Detroit went further in this category with 73 storeys. [7]
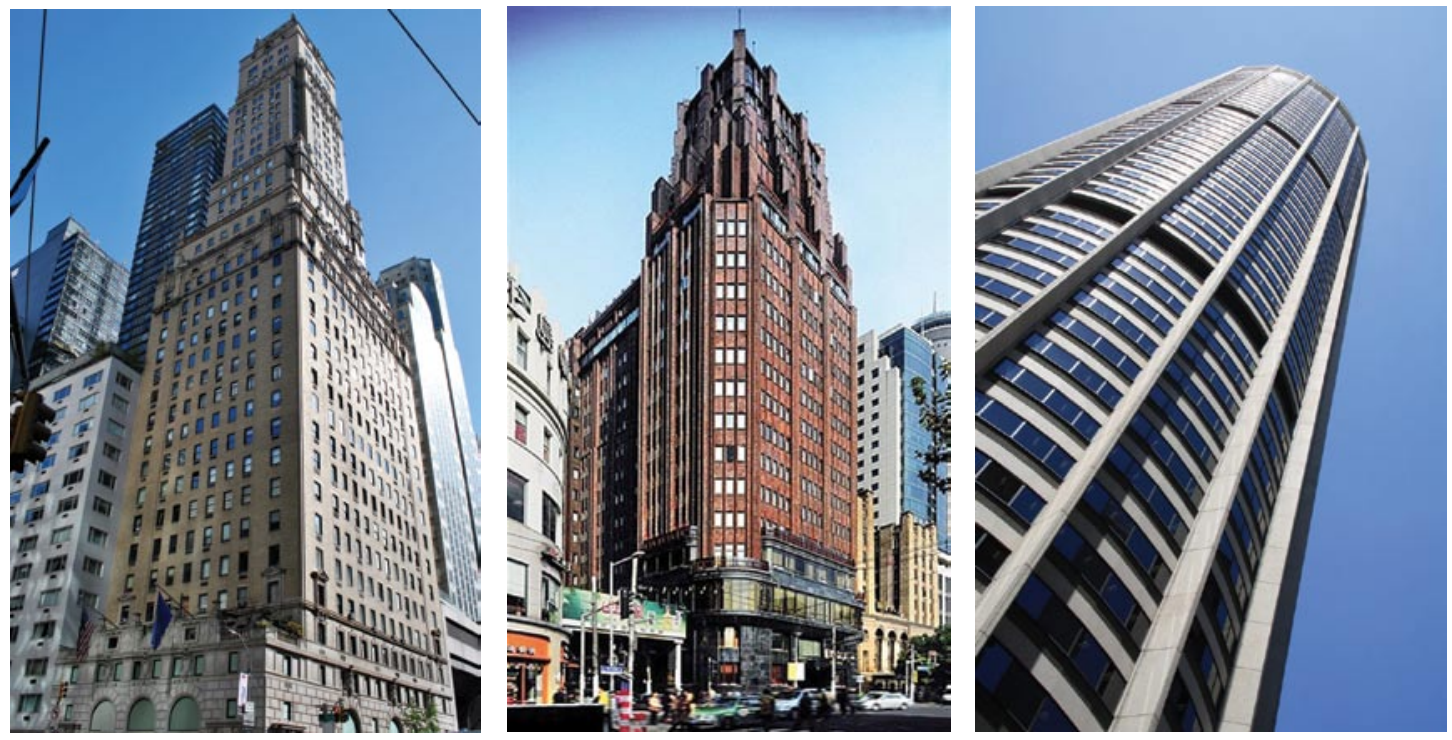

Figure 7. N.Y.C.'s Ritz Tower, Hudec's Park Hotel in Shanghai and Seidler's Australia Square Tower in Sydney

Looking at office towers, from the 1870's an interesting commercial phenomenon arose: companies tended to occupy only a part of their own space, making a convenient income from letting the rest. Furthermore, companies' presidents started to see their own buildings as giant signboards for free advertisement. [12] A mad race began back and forth between Chicago and New York as to which city had the highest skyscraper in the world, commanding prestige and generating monopoly rents. In New York City, that gradually became the capital of American corporate headquarters, in 1931-32 two of the tallest buildings of the world were erected: the 77 storey $(318 \mathrm{~m})$ Chrysler Building and the 102 storey $(381 \mathrm{~m})$ Empire State Building. The latter, a purely speculative building like the Chicago skyscrapers, was amazingly built in less than eleven months! (At the peak of its construction, the 3500 workers completed a floor a day!) The corporate tower gradually became the universal symbol of American cities and their cosmopolitan lifestyle. They were exciting and unconventional urban features, with many enthusiasts (as well as critics) considering them a symbol of modern civilization at the beginning, 

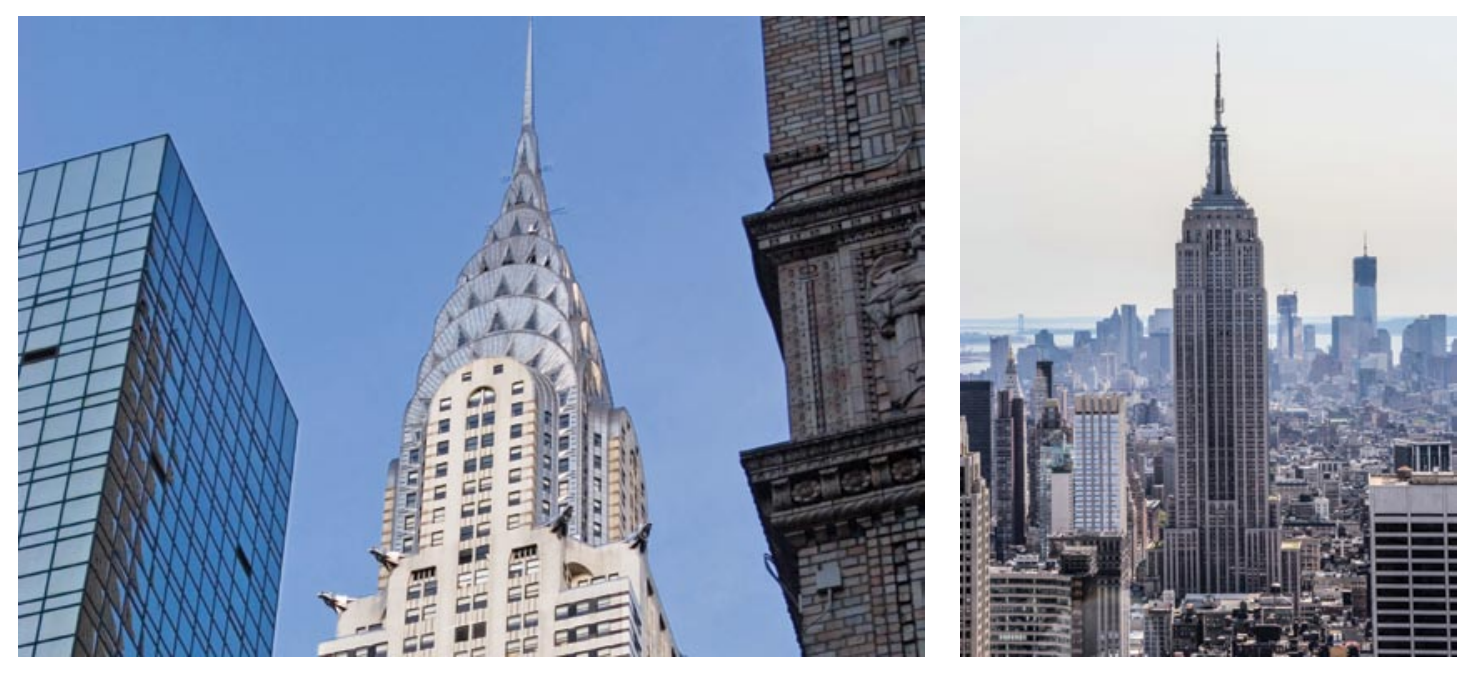

Figure 8. Iconic skyscrapers - early ones of NYC: the Chrysler Building (William van Alen) and the Empire State Building (William F. Lamb), and recent ones: the Swiss Re (Norman Foster) in London, the Hong Kong \& Shanghai Bank (Norman Foster) and the Bank of China in Hong Kong

(I. M. Pei and Leslie Robertson); they all have followed distinctly different design concepts, out of the mainstream international style of Modernism (or Neo-Modernism)

Looking briefly at the European landscape, the first skyscrapers were rather single episodes, like freak accidents. [5] In 1960, the Portland House (102 m) appeared in the storied townscape of London, then came Paris in 1972 with its single Tour Montparnasse (with its $210 \mathrm{~m}$ height, it was the tallest building in Europe at the time). Paris later let La Défense, the Corbusian skyscraper business district come about, soberly on the outskirts of its metropolitan area, while London, after a number of disastrous high-rise developments, designated its Canary Wharf in the Docklands as an enterprise zone where Europe's then tallest building (One Canada Square, $236 \mathrm{~m}$ ) went up in 1991. (Currently, The Shard is the European champion with its $310 \mathrm{~m}$ height, completed in 2010 in the same area.) In fact, 76 tall buildings (with more than 20 storeys) are due to be completed just in 2019, adding to London's skyline!
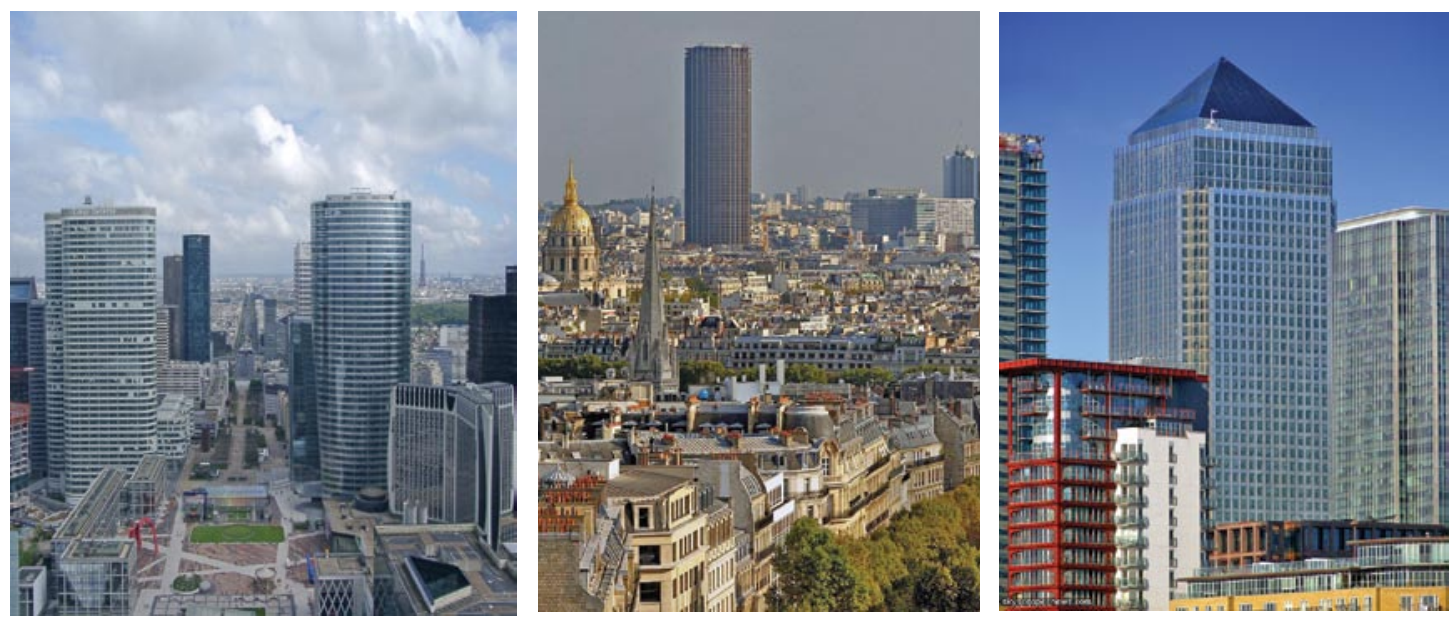

Figure 9. Paris' La Défense and Tour Montparnasse, and the One Canada

Square tower in London's Docklands (Canary Wharf) 
So since the early years, a myriad have been built in Chicago, New York, London, Paris, Frankfurt and elsewhere in the world from Latin-America to Asia. Many of them were pulled down or redeveloped since, according to the prevailing style of the time and due to changes in relevant zoning ordinances (e.g. the maximum floor space ratio and/or building height) permitting higher yields. In fact, the history of skyscrapers shows a remarkable parallel with the geographical evolution and shifts of capital on the world map. Now-days, of the tallest 100 buildings, 64 are located outside North America, and of these 41 are in Asia and 16 are in the Middle East. [11]

The nature of height contest is both generic (for international attention) and place-specific (fight for the actual city's skyline locally) in the same time. [5]. Fuelled by the power, pride and greed of major developers and/or politicians, it has been continuing ever, by now in an almost irrational range, moving towards the developing world, primarily to the Persian Gulf and Southeast Asia. (So much so, that among the 10 tallest buildings of the world presently 9 are in the Persian Gulf, China and Korea, and the only US contestant, i.e. the One World Trade Center of NYC on the site of the destroyed WTC, is only in the $7^{\text {th }}$ position.) One of the most significant contesters is China of course, however, there are newer and newer projects from India to South Korea and it seems that, after several decades, Frankfurt and Paris are also renewing their respective high-rise building programs. Even my hometown Budapest is, after half a dozen rather modest high-rise point block landmarks of the 1970's scattered around in the metropolis (in the height range between 60-80 m) and an enduring height limit, embarking on its first real skyscraper project (an off-centre corporate office tower).

Although these numbers change rapidly, it is also worth looking at the 2019 statistics of the most skyscrapers worldwide by cities. [14] Accordingly (in brackets is the number of buildings over $100 \mathrm{~m}$ height): 1 st Hong Kong (1405!), $2^{\text {nd }}$ New York City (796), $3^{\text {rd }}$ Tokyo (531), $4^{\text {th }}$ Singapore (521), $5^{\text {th }}$ Shenzen (401), $6^{\text {th }}$ Wuhan (379), $7^{\text {th }}$ Bangkok (369), $8^{\text {th }}$ Dubai (329), $9^{\text {th }}$ Chicago (327), and $10^{\text {th }}$ Shanghai (308). Actually, the number of skyscrapers (above $150 \mathrm{~m}$, or 40 floors) has risen, in a remarkably steady pattern, globally eight percent each year since 1950. [15]

As the stake is high, the definition and the comparison of height are worked out according to painstakingly elusive rules and until the last minute there is often some secrecy around the exact height of planned projects or the ones under construction (e.g. the Petronas Towers in Kuala Lumpur by Cesar Pelli). [6, 14] In fact, there are various categories applied by the Council on Tall Buildings and Urban Habitat (CTBUH) - tallest single-function residential, office and hotel, respectively, tallest mixed-use, or tallest steel structure, concrete structure and mixed structure buildings. (Height is measured from the footpath level of the main entrance to the architectural top of the building.) There are also records for the highest habitable floor, the highest enclosed space and the highest annex (pinnacle). The profession also applies the term 'vanity height', measured from the floor of the top storey to the pinnacle of the building, excluding flag-masts, antenna-spires and other equipments.

The absolute world record holders of recent times, however, were/is:

the $381 \mathrm{~m}$ high Empire State Building in New York City (from 1931 over 40 years),

the 417/415 m twin towers of the former World Trade Center in NYC (from 1972 for only 2 years),

the $442 \mathrm{~m}$ Sears Tower in Chicago (from 1974 for 24 years), the $452 \mathrm{~m}$ Petronas Twin Towers in Kuala Lumpur (from 1998 for 6 years),

(The 492 m Sanghai World Financial Center, 2008, could not

hold the title as 101 Tower was built in 2004, already )

the $509 \mathrm{~m} 101$ Tower in Taipei (from 2004 for 6 years), and 
the $828 \mathrm{~m}$ Burj Kalifa in Dubai (since 2010 on).

But the race must go on: by 2020 the Jeddah Tower in SaudiArabia may exceed the magic $1 \mathrm{~km}(1008 \mathrm{~m})$ height.

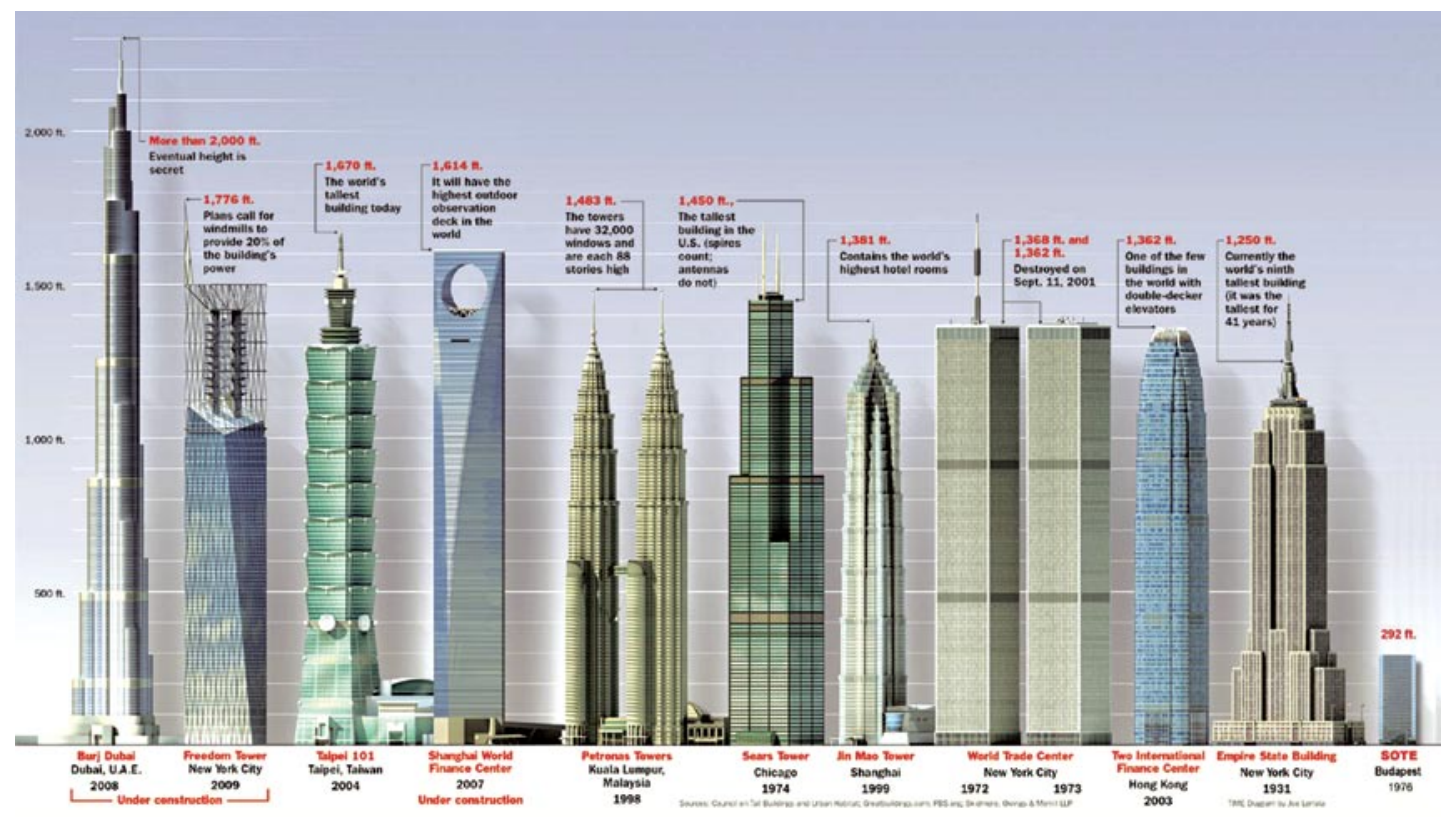

Figure 10. The first 10 highest buildings of the world
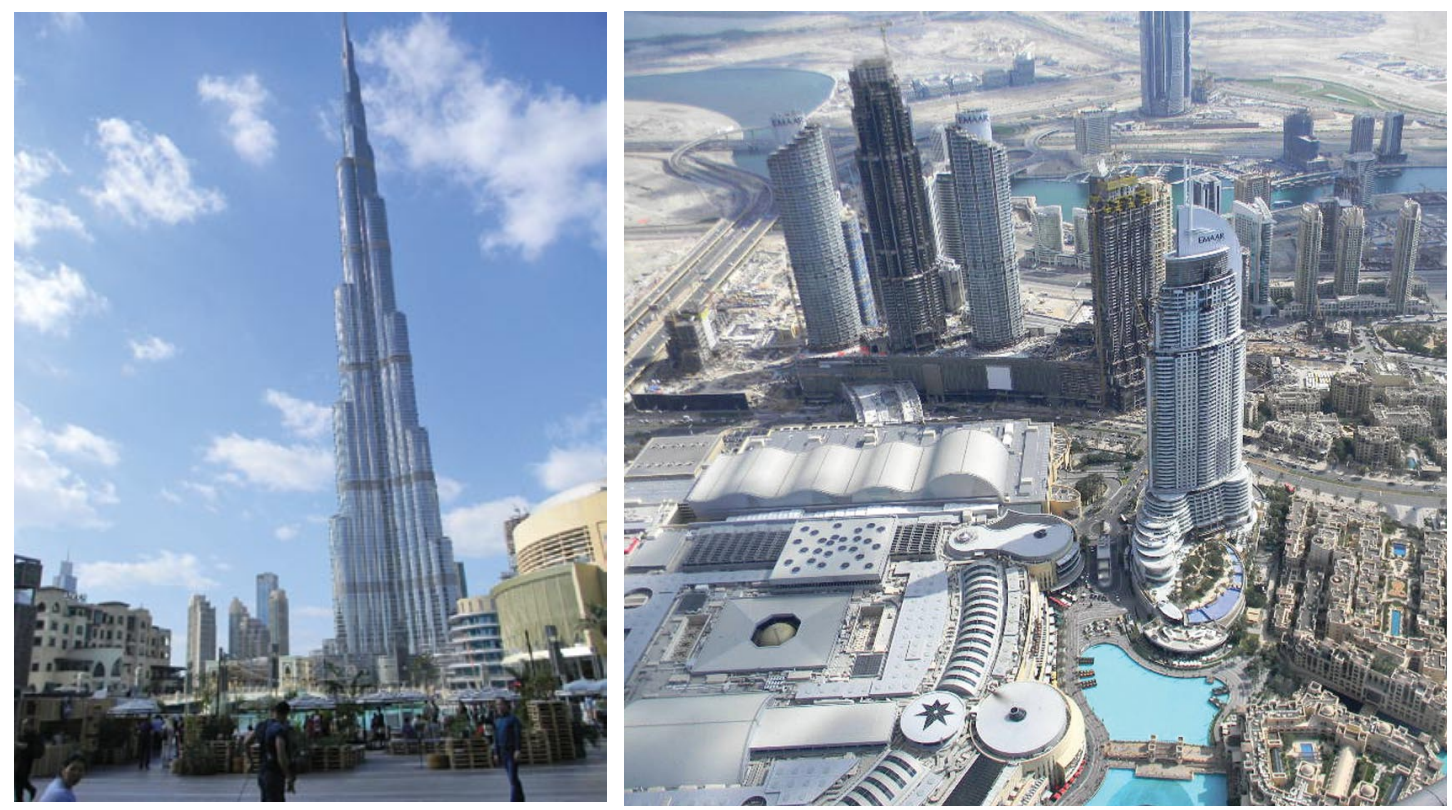

Figure 11. The champion so far: the stunning, mixed-use Burj Kalifa (by SOM) in Dubai $-828 \mathrm{~m}$ high with 163 floors and 57 lifts (accommodating observation decks, a hotel, corporate office suites and luxury apartments) and the breath-taking views from its $128^{\text {th }}$ floor observation deck (apparently, the nearby quite tall skyscrapers are all dwarfed) 
From a structural perspective (that certainly corresponds with the possible height of these buildings), there have been three generations: [11]

1) The first generation species had stone or brick exterior walls (sometime with cast iron), cast iron columns, wrought iron or steel beams and wooden floors. Elevator shafts were often open.

2) The second (pre-World-War II) generation ones are frame structures with welded- or riveted-steel columns and beams. The interiors are full of heavy load-bearing columns and walls. Windows could be open for local ventilation (e.g. the Empire State Building).

3) After World War II, the third generation of tall buildings are of either steel-framed, or reinforced concrete-framed or combined (steel-framed - reinforced concrete) constructions, typically with all-glass and steel (mullions) curtain walls on their facades.

The actual height contest above roughly 40 floors has been made possible by the invention of the Bangladeshi-American structural engineer Fazlur Rahman Khan (1929-1982). His 'tube in tube' new structural system, developed in the 1960's, provides more economical layout (floor plans) and also makes more flexible shaping of the building-mass possible. Breaking away from the rectangle and the 'box-like' appearance, buildings could become sculpture.

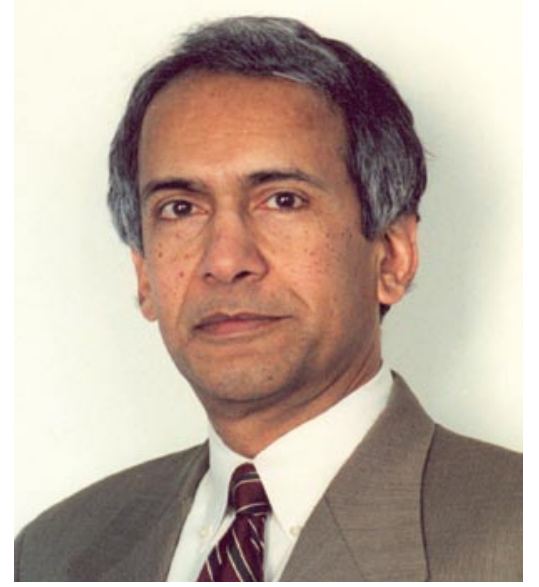

But with their ever growing height and the consequently accommodated crowd of these huge buildings (equalling with a small town population), the vulnerability of them has also been growing in physical and symbolic sense alike. Just take the huge loss of lives as well as the symbolic significance of the destruction (from the perspective of both the US and the terrorists) of the WTC twin towers in N.Y.C. in 2001. It is tempting to look at it symbolically as the modern equivalent of the Ancient Tower of Babel.

Figure 12. The late Fazlur R. Khan, a representative of the 2nd Chicago School

\section{DECONSTRUCTING SOME MYTHS - THE URBAN DESIGN PERSPECTIVE}

As far as the urban context of high-rise buildings is concerned, they, as a design pattern, can be either

- a non-thematic element in low(er)-rise urban environments or 'floating' in open (green) space, used as landmarks/vertical accents in a larger metropolitan area, or

- thematic elements, typically either in the central business district (and/or in sub-centres) of a metropolitan area or in high-rise housing estates.

Height, however, is a relative matter, relative to the building's surroundings. Looking at the skyline of historical cities, they used to be dominated by civic and religious buildings of public significance: churches, post offices, town halls, railway stations etc.

Skylines of most contemporary cities are dominated by publicly irrelevant buildings: office towers of insurance companies, investment banks, pension funds and multinational companies. 
A general increase in the scale of ordinary buildings has overpowered the traditional public symbols of the skyline and hence the legibility of the city has been eroded. $[5,10,21]$ The cityscape has been transformed and privatized by profit-maximising developers and the new technologies, respectively. Let us also add, however, that lately, with a variety of (tapering, oval, spiral or complex) shapes and elaborate cantilevered or raked tops, they make more lively skyline at least. [5]
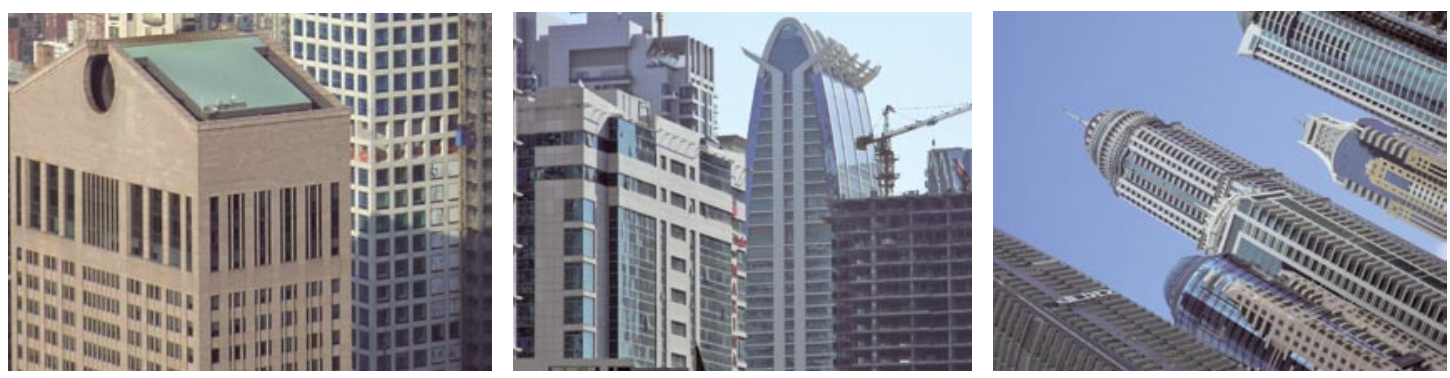

Figure 13. Philip Johnson's AT\&T building in Manhattan with the iconic broken pediment on the top and roof variations in Dubai's Marina Bay

The 179 m high residential Marina City in Chicago, completed in 1964, has set a new and important category in high-rise typology: it was the first skyscraper complex with twin towers. [16] (See its successors worldwide, e.g. the former World Trade Center in N.Y.C., the Century City Towers in Los Angeles, the Petronas Towers in Kuala Lumpur, the Rialto in Melbourne, the Bahrein World Trade Center or the much more modest Hermina Towers in Budapest, built later on.) When finished, the two circular 65 storey reinforced concrete towers were actually the tallest residential building(s) in the world.
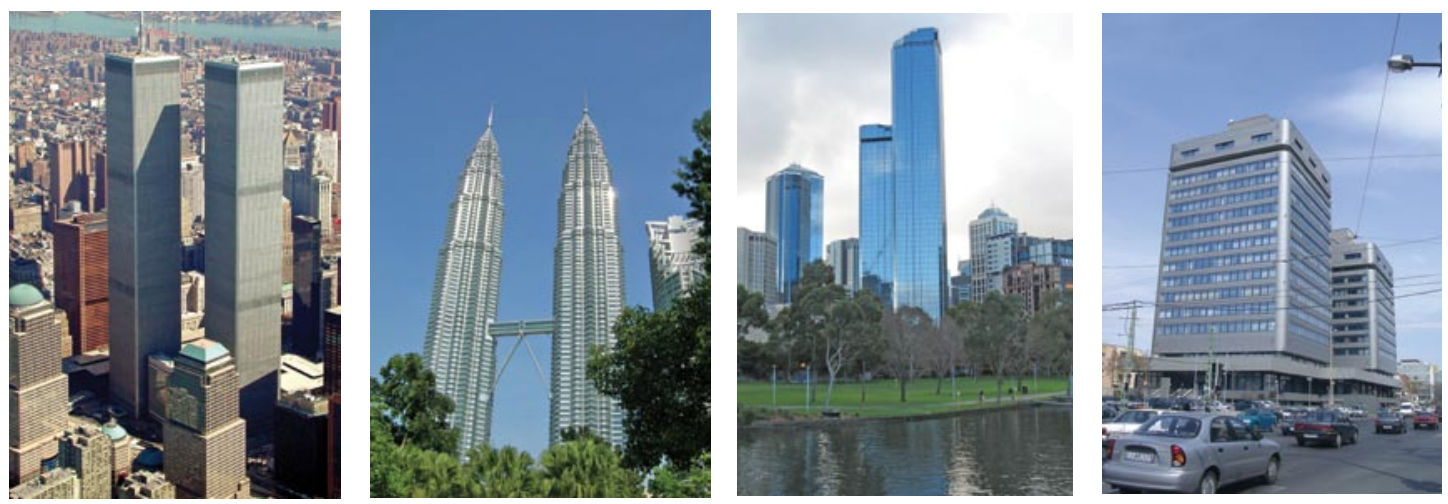

Figure 14. Twin high-rise towers: the former WTC in N.Y.C., the Petronas in Kuala Lumpur, Melbourne's Rialto and the Hermina Towers in Budapest

There seems to be a paradox concerning their layout in intensified centres. Ideally, skyscrapers were mid-space urban units (all standing free in vast open parks without enclosing space as Corbusier suggested) to be admired from all sides and to command a large visual territory, but practically, as thematic elements, they often have to function in a relatively finegrained street grid and block structure where the more is crammed into this confined area the more each one is deprived of this 'breathing space'. [5] 
One aspect of their criticism has been the erosion of traditional urban fabric of enclosed spaces, due to the discontinuity of street level activities and the streetscape, respectively. One usual remedy for this is the application of 2-5 storey podia upon which the point blocks (towers), as monumental mid-space masses, are placed. These podia may then function as space-defining walls providing continuous street level facades and activities. (Furthermore, the podium is often a necessary measure for calming artificially generated downward gusts, too - see more on this later on.)
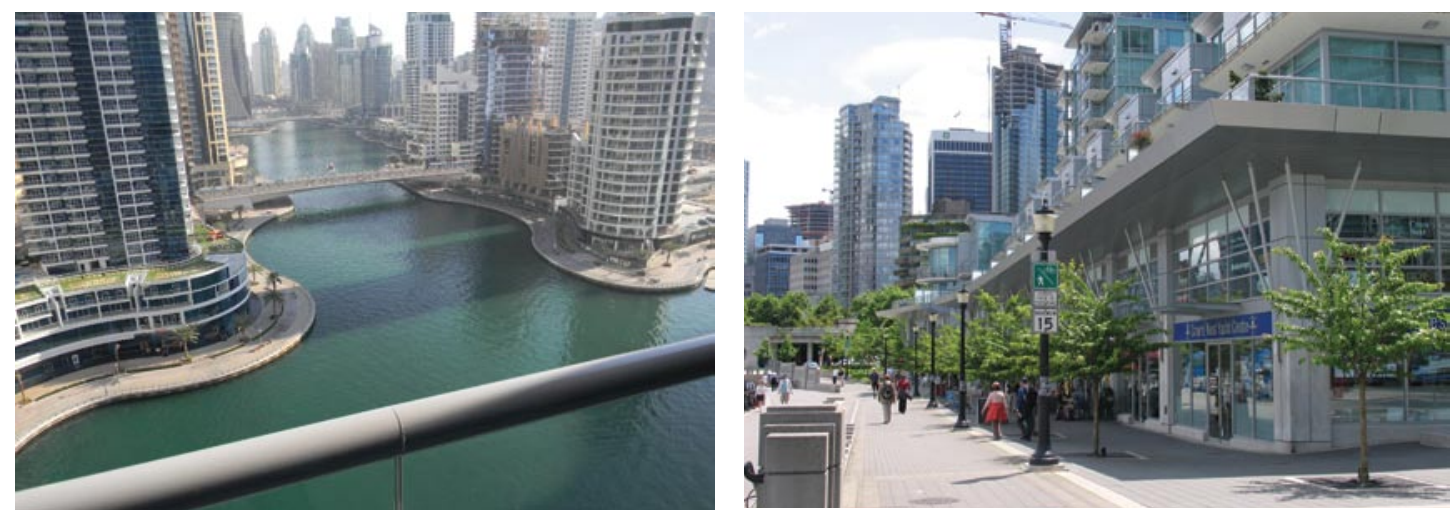

Figure 15: Street level enclosed space and pedestrian experience are provided by podia (Marina Bay, Dubai)

Density as a defining factor has been central to the debates on the question of urbanisation well over fifty years. Although, it has been often claimed that capitalist urbanisation processes provide the most efficient use of land, but in fact it is not the case. [9] As to form generation (i.e. the relation between built form and spatial efficiency), some fundamental scientific research was conducted in the 1970's in the Cambridge School of Architecture. The findings were published in two important books by Leslie Martin and Lionel March (Urban Space and
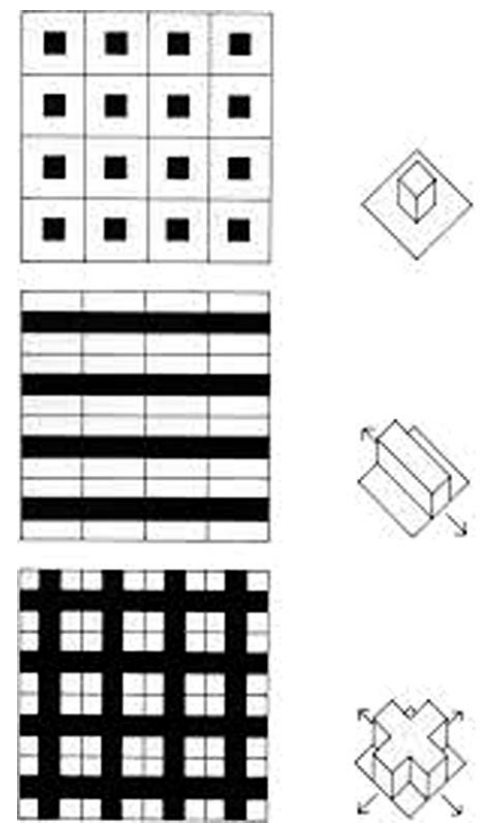

Structures, 1972) [17], and Lionel March and Philip Steadman (The Geometry of the Environment, 1974) [18], respectively, that represent a landmark in our understanding of built forms.

Without going into sophisticated details of their mathematical modelling, their findings are pretty straightforward and managed to clarify some previous misunderstandings about built form and spatial efficiency, definitely separating facts from myths and intuitions. (By spatial efficiency the total length of internal access spaces/corridors in relation to gross floor space was meant.) The surveys were conducted with various density figures as function of the plot ratio and continued with the implications of a range of building forms.

Figure 16: The three generic layout patterns studied in relation to density - free standing pavilion (mid-space tower), linear (on street) development and perimeter (courtyard) block [17, 18] 
It was clearly demonstrated that, on the one hand, the relationship between the form of a building and the land upon which it is built is not arbitrary, and on the other, that under specified conditions (e. g. exact light angles, the same land area, and the same number of floors), one particular building layout can provide 50 percent more floor space than another! It was also pointed out that this (abstract) spatial efficiency is inversely proportional with building height, given the basic principles of perimeter planning. [9]

With the analysis of the three generic layout patterns, it was also proven that, at 50 percent site coverage each, the perimeter block provides the same amount of build form (floor-space) for approximately one third of the building height than its inverse (i.e. the 'anti-form' midspace point block tower or pavilion). Thus, this particular layout geometry offers far more environmental benefits than the others. Regardless, since the invention of steel frame and the safety lift, the free standing pavilion is the dominant building type in most CBD's, offering the least spatial benefit. (But it is also worth noting here that the above models focused purely onto the geometry of the layout, omitting other important potential intervening factors, e.g. politics and policies, economics, market forces, saleability, culture, law, ownership, development control, history, and existing built form, among others.) This relationship becomes definite, however, with other considerations (e.g. the definition of net density, among others). In overall, perimeter planning increases in efficiency with increases in physical scale. [9]

In the light of these research findings, we might conclude that there is no real (pure technical and/or planning) rationale of building high-rise (by the same token, it must not be an accident that the dominant layout pattern of historical urban fabrics has been the traditional perimeter/ courtyard block), except in case of extreme land shortage with forced densities and land speculation - i.e. developers' extra profit in the form of (monopoly) rents. (Good examples for this are Singapore and Hong Kong confined by their topography, i.e. peninsula/island, mountains and the sea. For example, land supply in Hong Kong was so limited by the 1840's already that even underwater lots in central were being auctioned off!) [19] Despite all the above scientific investigations, there is still much stereotype involved in planning practice, due to the frequent confusion over the relationship between building height and density, as to highrise can be built at lower densities than low rise, and vice versa - all depends on site coverage. (The concept of rent occupies a critical position in relation to high-rise development, as it provides the connection between political economy, spatial location and built form. With some sophistication, Marx distinguished between 3 types of rent, which represent the main methods of expropriating profit from land development: monopoly rent, absolute rent and differential rent. Without going into details, they are responsible, among others, for creating particular urban forms, perhaps the most important being high density development, as it maximises the owner's interest and reflects land prices at central locations.) [9]

Just touching upon related development control matters, basically there are two alternatives: 1) either discourage it altogether, or 2) regulate the proliferation, siting and appearance. Height limits are a recurrent theme in city-making. Ancient Rome had them already, and so did Medieval London (though they had to do primarily with structural and fire safety). [5] In the period of the 19th-20th centuries in shaping the skyline, cities exempted certain buildings from prevailing height restrictions (e.g. London, Stockholm, Los Angeles). Restrictions on highrise existed as early as the 1880's in Chicago (which had doubled by 1920). In practice, some (local) governments used absolute numbers (e.g. Chicago, Boston, Washington DC or some English towns) while others (e.g. New York's zoning ordinance of 1916) applied the concept of setbacks and determined the maximum permissible building height as a multiple of street width. 
Presently, there are also several approaches to the application of high-rise in terms of geographical position and over time.

Even within the Old Continent quite different policies exist. At a glimpse of the New World, in New York's Manhattan, since early on 3D building envelopes determine their permitted mass (size, height, shape and vertically varying setbacks). In San Francisco's and Sydney's CBD for example, before the approval of a high-rise design proposal, it is carefully assessed for generated adverse wind patterns and overshadowing, and if any fails to meet the set maximum standards, the proposed building must be redesigned accordingly. An additional aspect of height limits that has come into the picture, is aviation safety that affects the navigable airspace over cities (including flight corridors and no-fly zones).

In many parts of the world, a negotiable bonus system is also applied, i.e. if the developer contributes to the improvements of nearby public infrastructure or public facilities/amenities (e.g. with a new kindergarten, public library, pedestrian overpass, passage through the block or new open space), it is granted extra floor space (practically extra storeys) to build.

In Europe, there are historical cities where no permission is given to any high-rise development at all.

Even those who permit them, apply strict controls, and do it in three different ways: - either they are permitted outside the centre (often on the metropolitan edge) in a designated and concentrated location only (e.g. Paris' La Défense and Vienna's UNO City/International Centre or Bonn's government offices); - or in carefully selected, scattered singular locations (usually near major interchanges of the major road and the public transport networks), punctuating the city-form with 'exclamation marks' to enhance large scale legibility and the silhouette of the metropolis (and certainly to manage substantial extra traffic generation by them); - or a few cities give room for high-rise building(s) even in theircentre, in the vicinity of their historical core (like Frankfurt or Paris earlier with its Tour Montparnasse) through individual assessment.

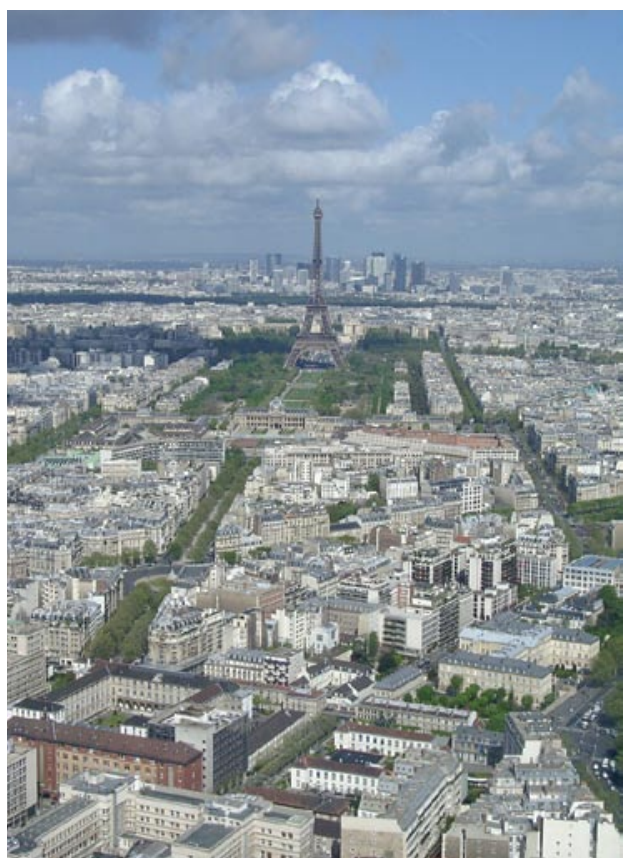

The above list clearly demonstrates that beside market driven high-rise building (e.g. Frankfurt or many American type CBDs), there is a distinctly different case: i.e. the planning policy driven high rise development/siting (e.g. Paris, Vienna or Budapest, but even the former WTC, developed by the Port Authority of New York and New Jersey).

Figure 17. The spectacular panoramic view of Paris from the $59^{\text {th }}$ floor of the (the otherwise ugly) Tour Montparnasse 


\section{PLANNING CONSIDERATIOS AND DESIGN CHALLENGES}

Now, let us have a look at the list of considerations, essential for developers, designers and statutory administrators of urban policies alike, to appropriately judge the justification of highrise building proposals.

They are as follows:

- conscious shaping of the city's skyline with well-placed landmarks to increase userlegibility,

- the position of the building lot in the metropolitan structure (centre, sub-centre, at major intersection of the main road network and/or high capacity public transport interchange), in conjunction with the above,

- opportunity to carry symbolic messages in assisting place-marketing (i.e. the metropolis) in the competitive international arena,

- creating look-out opportunity to appreciate panoramic views of the landscape (but it benefits the public only if a look-out deck and/or restaurant, open to the public, are provided, otherwise it is purely profit-making),

- the potential reserve capacity of the existing road and public transport networks affected (to appropriately handle extra traffic generation),

- he developer's contribution (DC; i.e. sharing its profit with the public) that may finance necessary public infrastructure improvements in the vicinity, and

- land prices and the supply of building parcels, respectively.

The difficulties encountered in skyscraper projects are among the most complex problems as a fine balance is required among economics, engineering, architecture (i.e. functional needs and aesthetics) and construction management. As far as the actual design and the operation of the building are concerned, particular attention must be paid to the following issues:

- optimal tenant mix (besides location and services offered, the variety of available rentable spaces also counts) - these issues are to be considered in the business case, already, in conjunction with marketing and operational aspects,

- economical ratio of gross and lease-able floor-spaces - the necessary area occupied by, in most cases, the inner reinforced concrete core ('enclosed box' with the shear walls and vertical services, such as fire-stairs, lifts and various ducts/pipes) providing lateral stability, increases significantly with the height of the building and that un-proportionally reduces the rentable floor-space, especially over $100 \mathrm{~m}$ height (for this reason, there have been some structural innovations and experiments with outer cross-bracing and the 'tube in tube' systems for superhigh buildings);

- structural rigidity - the lateral loads (primarily by winds and earthquakes) of this, proportionally slim vertical console may produce oscillation/sway in the order of $0.3-0.5 \mathrm{~m}$ amplitude at the top of the building which can create significant discomfort for users, reduce usability and may damage some joining structures, paving and the connections of engineering services (even additional mass dampers to reduce vibrations and swaying and/or gaps to allow air to pass through, reducing wind shear may be required; e.g. see the computer-controlled dampers on the top of the Citicorp Center in New York) [7, 13];

- wind patterns generated by the building (their impact can be mitigated or largely reduced with the adequate shaping of the building with setbacks and/or podia);

- due to the strong competition and the generic endeavour to produce memorable iconic buildings, asymmetry, inclination and vertical twisting are often used as architectural 'stunts' in recent design concepts - if these geometrical deviancies are not reduced to the facades but affect the whole structure, significant additional stresses are to be handled by special smart engineering solutions [16]; 
- the number of lifts required increases with number of floors to be serviced and so does the area they occupy, further reducing the useable floor-space - therefore some innovative arrangements are needed to spare space (e.g. the combination of express lifts servicing designated higher floors and local lifts operating from those platforms in the same shafts on the top of each other, or two-storey lifts with double decks that service every other floors);

- the foundation is far more simple and less expensive if the load-bearing bedrock is near the surface (like in some parts of Manhattan or in Sydney's CBD);

- above a certain height, special (and expensive) solutions are required for certain engineering services - examples include water pumps to ensure adequate pressure on higher floors as well, a water reserve on the top (both for stabilizing water pressure and for fire fighting, but it may contribute to the stability of tall structures, too) and doubled waste water collection system on each floor (main ducts complemented with joining local ones) to avoid the sucking-off of the odour-blocking water reserves in sanitary equipments; and

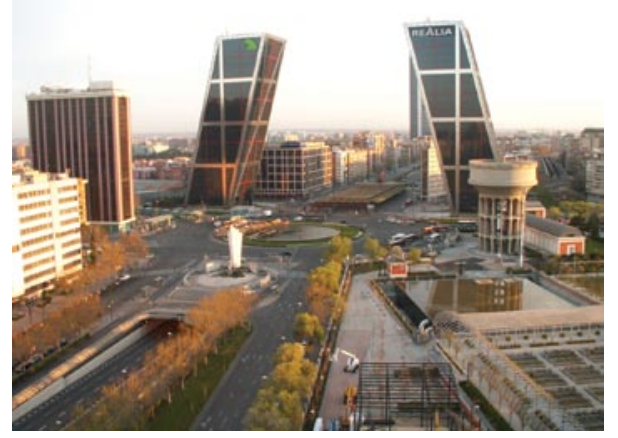

- safety and security (with special attention to fire, suicides and terrorism) with all their implications (insulation/protection of structural steel, necessary space and access for related operations/actions, special networks and equipments of telecommunication, detection and control).
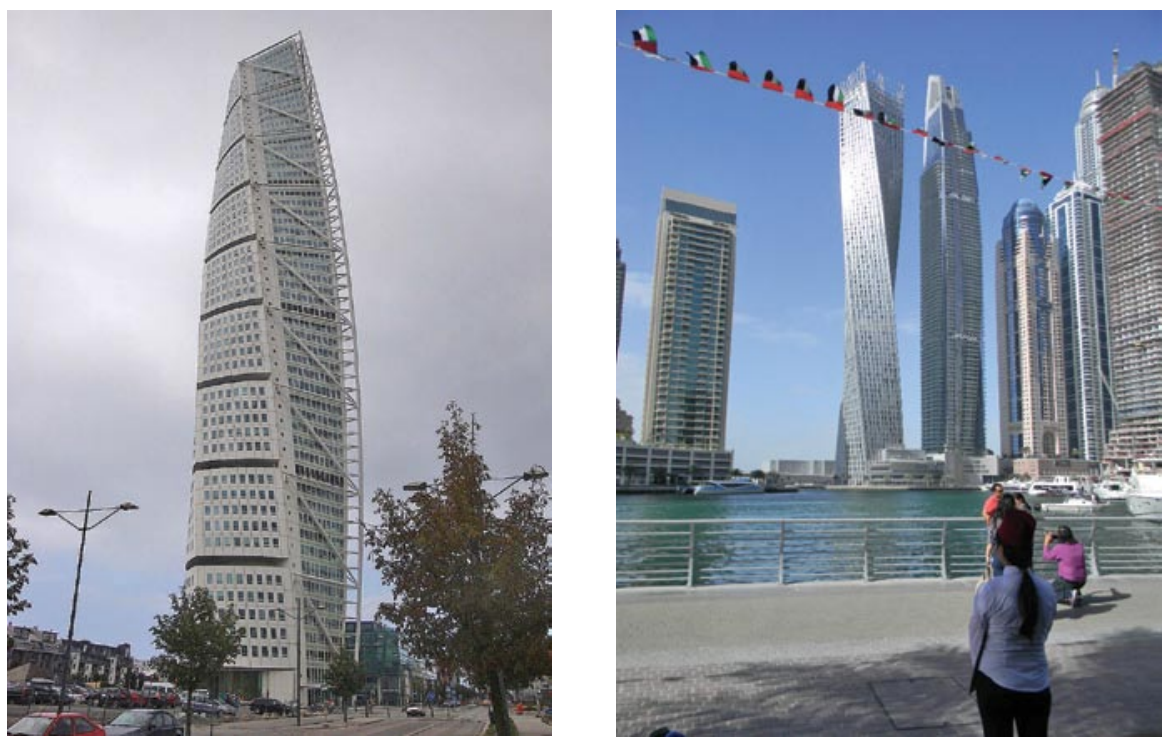

Figure 18. Iconic 'deviant towers': the residential HSB Turning Torso of Malmö (2005, $190 \mathrm{~m}$ high with 54 storeys, by S. Calatrava - the first twisted skyscraper in the world) and one of its 'clones', the Cayan Tower (2013, 306 m by SOM) in Dubai's Marina Bay - they mimic the shape of the human DNA; and the leaning Gate of Europe (or KIO) towers in Madrid (1996, $114 \mathrm{~m}$ high with 26 storeys each, by Philip Johnson and associates - the first inclined skyscrapers in the world) 
In the course of the structural design of skyscrapers, a myriad of impacts and their interactions need to be analyzed, both static and dynamic. Perhaps the most striking challenge is that their dominant (typically horizontal and dynamic) loads (especially above $200 \mathrm{~m}$ ) are created by the permanent strong wind and the occasional seismic effects. (In addition, the former ones call for structural rigidity to provide user comfort on the top floors, too, while the latter ones require structural flexibility.) [16]

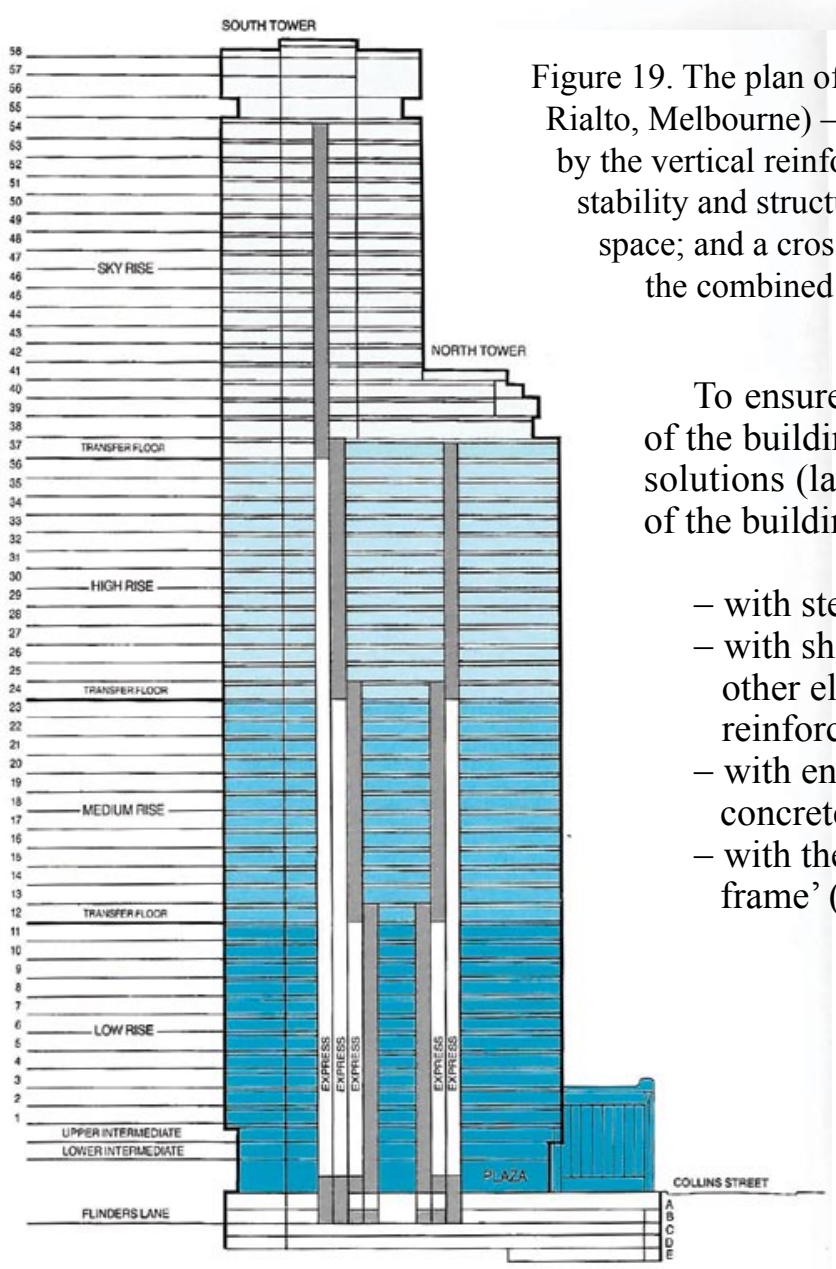

Building Profile

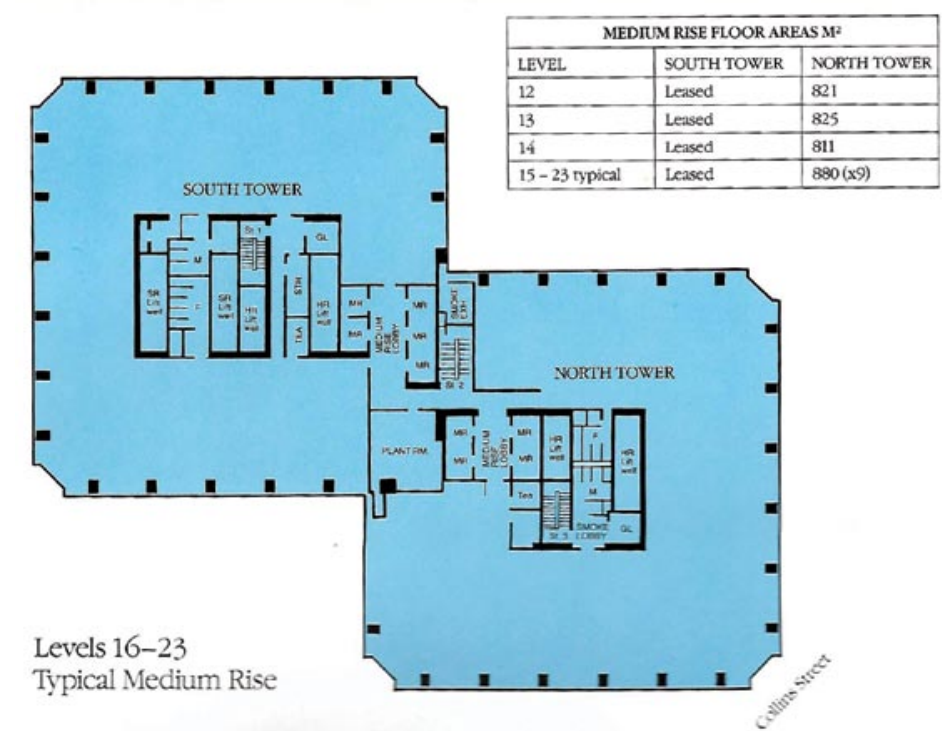

Figure 19. The plan of a 50 storey skyscraper at midway (The Rialto, Melbourne) - it shows the ratio of the area occupied by the vertical reinforced concrete service core (providing tability and structural rigidity) and the lease-able floor pace; and a cross-section of the same building with the combined elevator system (sparing room)

To ensure the stability (i.e. the lateral rigidity) of the building, there are a number of engineering solutions (largely depending on the actual height of the building):

- with steel frame,

with shear walls (usually combined with other elements, e.g. post-stressed reinforced concrete slabs),

with enclosed ('box'-like) reinforced concrete vertical core, or

with the 'tube in tube' and 'cellural-tubeame' (or tube-bundle) systems. 


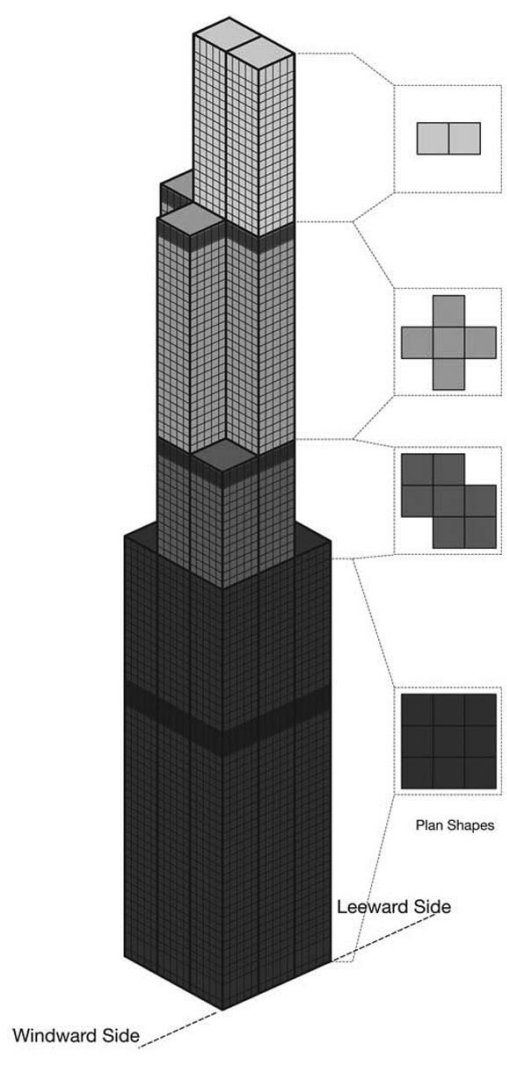

Figure 20. Khan's 'tubular' structural system

The 'tube in tube' structural system that revolutionized tall building design (invented and developed by Fazlur R. Khan with Leslie Robertson in the early 1960's) consists of 3-4 (or more) typically outer frames built into and connected with each other. In fact, the exterior wall perimeter structure is treated like a hollow cylinder (or thin-walled tube). Thus, a major part of the load-bearing structure has got back onto the façade, albeit in a very different manner. They are dominantly made of steel but earlier reinforced concrete was also applied (e.g. at the twin towers of the World Trade Center, N.Y.C.). In this system, the outer vertical and horizontal support members with the cross-bracings permit the use of less pillars inside, which leaves more usable floor-space to be let. But these elements in return, occupy about half of the surface of the facades and consequently the room for windows is largely reduced (not to mention the difficulties arise with wider openings, such as garage gates on the ground floor). So much so that, for example, most of the windows were only $55 \mathrm{~cm}$ wide on the WTC, due to the load-bearing steel mullion system on the facades.

A further development of the tube system was his 'cellural-tube-frame' (tube-bundle) concept that consists of several interconnected bunches of 'tubes' terminating at different heights (e.g. the Sears Tower in Chicago or the Burj Kalifa in Dubai). In fact, Khan pioneered several variations of the tube structure (i.e. framed tubes, tube-bundle, X-bracing, or 'tussed-tube'). With these structural systems both materials used and associated costs can be significantly reduced and bigger heights can be economically achieved, respectively. Since the 1960's, most of the buildings of more than 40 floors are built with these structural systems.

But above 80-100 floors that is not enough either: in the range of mega-heights, in addition to the tubular concepts the structure and the consequent shape of the building must follow a pyramidal form (either with tapering or with a series of setbacks) whereas, following the stress diagram of a console, the plan (footprint) of the ground floor is much larger than the top of the building. This is the so-called 'skeleton system' (see e.g. the Dubai Burj Kalifa and the Transamerica Pyramid or the Salesforce Tower in San Francisco). [16]

As to the impact of tall buildings on nearby pedestrian environment, particular attention must be paid to adverse wind-speeds (draughts) generated by and around tall buildings. Here 'tall' simply means that a building is at least twice as high as it surrounding built environment. These artificial wind patterns have been analyzed and typified by the Environmental Simulation Laboratory of the University of California at Berkeley. [20] (However, there has been some research conducted in the topic in France, too.) Ten different urban wind effects have been identified, out of which the strongest and most critical ones are:

- the downwash vortex,

- the corner effect and

- the wake effect. 
(When more than one building is involved, wind disturbances can become more complicated and far more severe.) The most frequent and severe is perhaps the downwash vortex flow at the foot of tall buildings. Because the wind's speed increases with the height, the pressure that builds up on the building's windward face is higher at the building's top than at its base. The difference in the pressures creates a strong $(30-75 \mathrm{~km} / \mathrm{h})$ downward flow. Once it reaches the low pressure zone at the ground level, the down-draft turbulently spins around, further adding to the significant discomfort hitting pedestrians at ground level. The general effective remedy for that is the appropriate shaping of the building (i.e. with various setbacks and/or a podium of a couple of storeys, upon which the tower part is placed). Thus, it is the roof of the podium that is hit by the down-draft, performing as a shield for the nearby street level pedestrian environment.

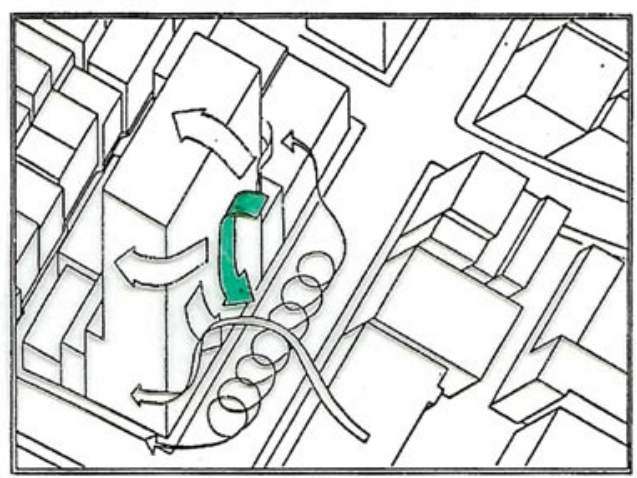

Downwash Wortex

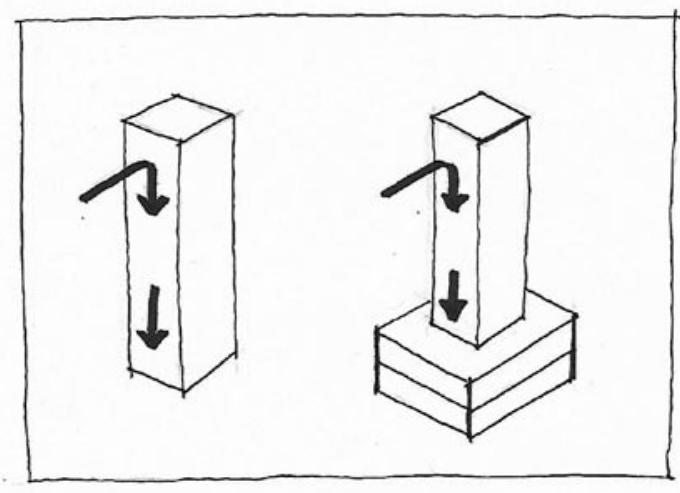

Figure 21. Urban wind patterns generated by tall buildings - the strongest being the downwash vortex; and the remedy: the podium [20]

\section{THE LATEST TRENDS}

The next era of skyscrapers must, without doubt, focus on the environment, including the types of materials, the least use of these materials and energy, the construction practices, smart building technologies and most importantly the concept of sustainability and a holistically integrated building systems approach, in overall. [13]

If an old skyscraper was no longer needed for some (mainly economic, i.e. profit making) reasons, earlier almost all had been torn down, to be replaced by even taller ones. (Certainly, the cost of their removal must be absorbed in the profits of their successors.) Now-days, due to new environmental trends, they are often upgraded either for the same use (including the facade, the services and some form of alternative energy) or for other use (e.g. converted from office to residential). [10] 


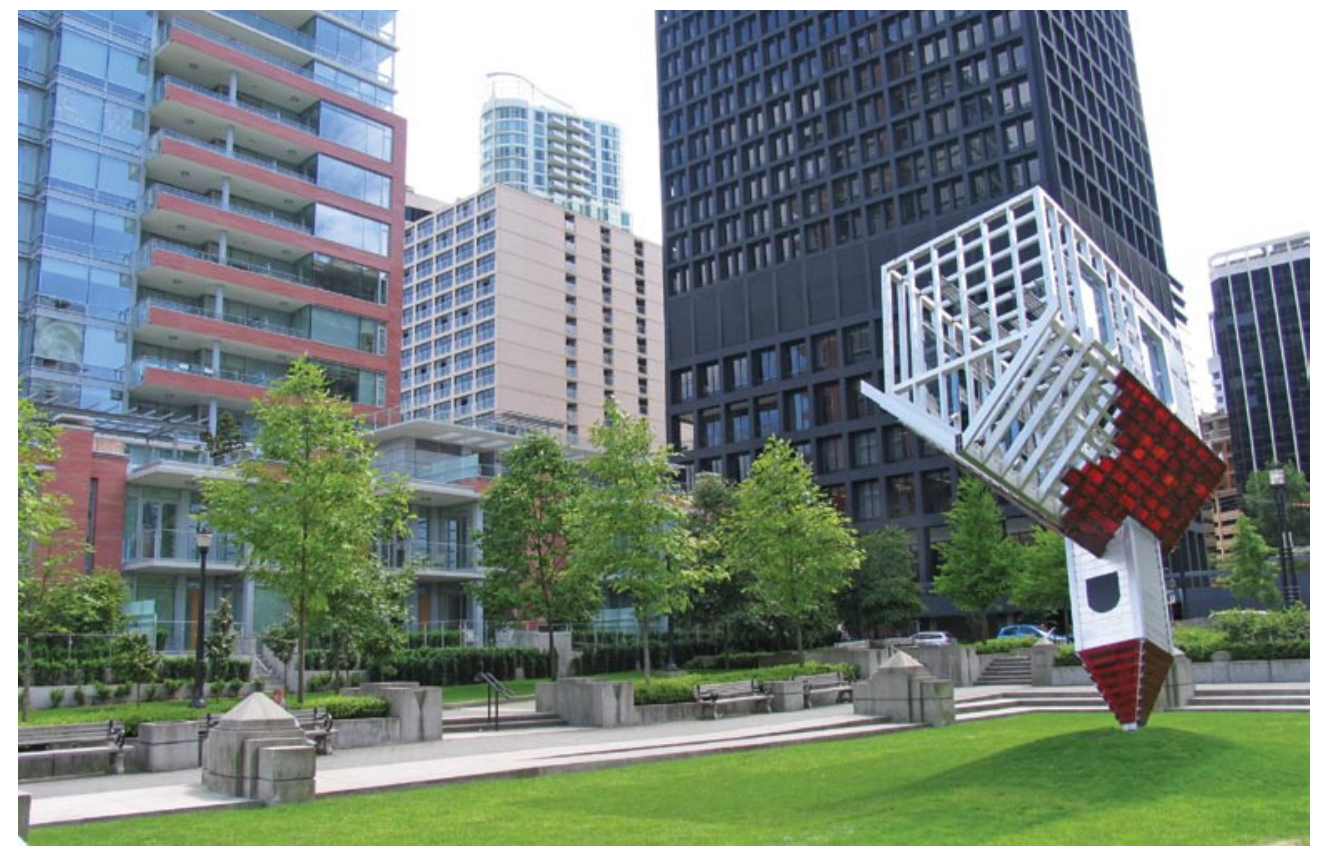

Figure 22. Recycled high-rise office tower for residential use, Downtown Vancouver

A relatively new concept in 'vertical architecture' is the development of sustainable 'ecotowers' or 'green skyscrapers'. It is certainly not free from ideology either. [9] It is not simply about green roofs, water and solar panels, i.e. adding further dead load to the supporting structure (the roof of very tall buildings is not suitable for this anyhow, except for storing the necessary servicing hardware the building needs), but about fundamentally new approaches as it was stressed for example in the proceedings of the Eco Tower Seminar held in 2001 in London.

The highest profile authority of this revolutionary new concept is the Malaysian 'ecoarchitect' Ken Yeang (1948) with immense practical experience and scientific knowledge in the field. (He graduated from the AA School of Architecture in London and did a PhD in ecological design in Cambridge, but he also attended courses in ecology at Cambridge University and ecological land use planning at the University of Pennsylvania). He has pioneered an ecology based architecture to minimise the impact on the environment, more specifically low-energy passive design for high-rise buildings since 1971 (!), including research, publications, lectures and over 12 completed bioclimatic eco high-rise buildings (among many other projects).

The approach he has developed for low energy 'green skyscrapers' is eco-mimicry. Central to his concept is the symbiosis and the ecological balance between high-rise buildings and their environments. He claims that his buildings are sustainable in all aspects, be it recycled materials, energy generation and consumption, the usage of the existing infrastructure and services and the new communities coming about in them. His design has abandoned traditional building forms and is radically green where aesthetics, micro-climate, air ventilation, solar gain, carbon-dioxide emissions and biodiversity are all improved with vegetation/plants. 
As far as energy demand and innovative design features are concerned, there have been some interesting projects recently. One example is the $240 \mathrm{~m}$ high twin towers of the Bahrein World Trade Center (2008) with fifty floors. It is the first skyscraper of the world to integrate wind turbines that generate about 15 percent of its own energy consumption. Another one, the $420 \mathrm{~m}$ high mixed use Dynamic (or Da Vinci) Tower is in the pipeline in Dubai (scheduled originally for 2020) by David Fischer. It is apparently delayed, but if realized, it will be the world's first skyscraper of separate (prefabricated) rotating floors (similar to the 15 storey, 50 $\mathrm{m}$ high spinning Suite Villard in Curitiba, Brasil, 2001), equipped with wind turbines and solar panels which are to provide even surplus energy for nearby buildings. The 'greening' concept is getting into the mainstream: e.g. Paris' Tour Montparnasse is due to get a costly 'sustainable' green makeover in 2019.

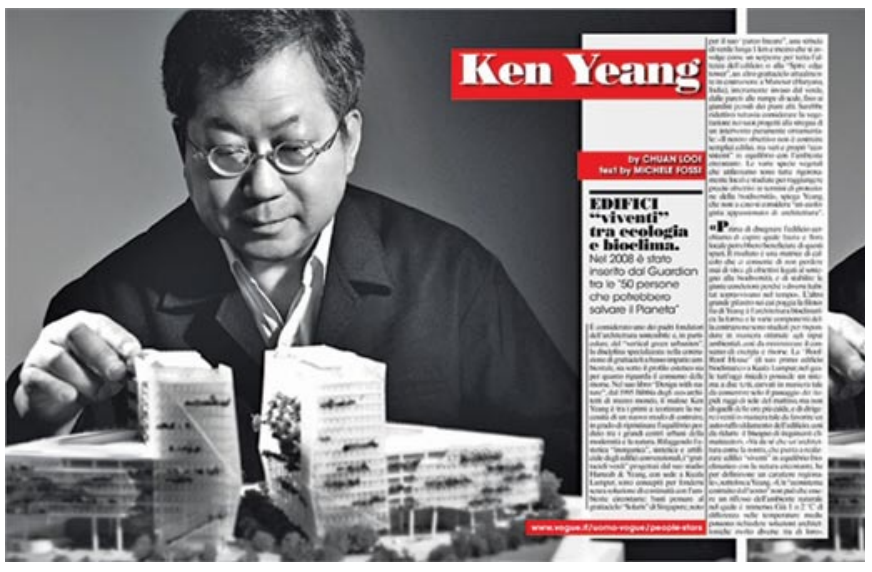

Figure 23. Recent trends $-\mathrm{K}$. Yeang in the Italian edition of the Vogue Magazine and one of his eco-towers
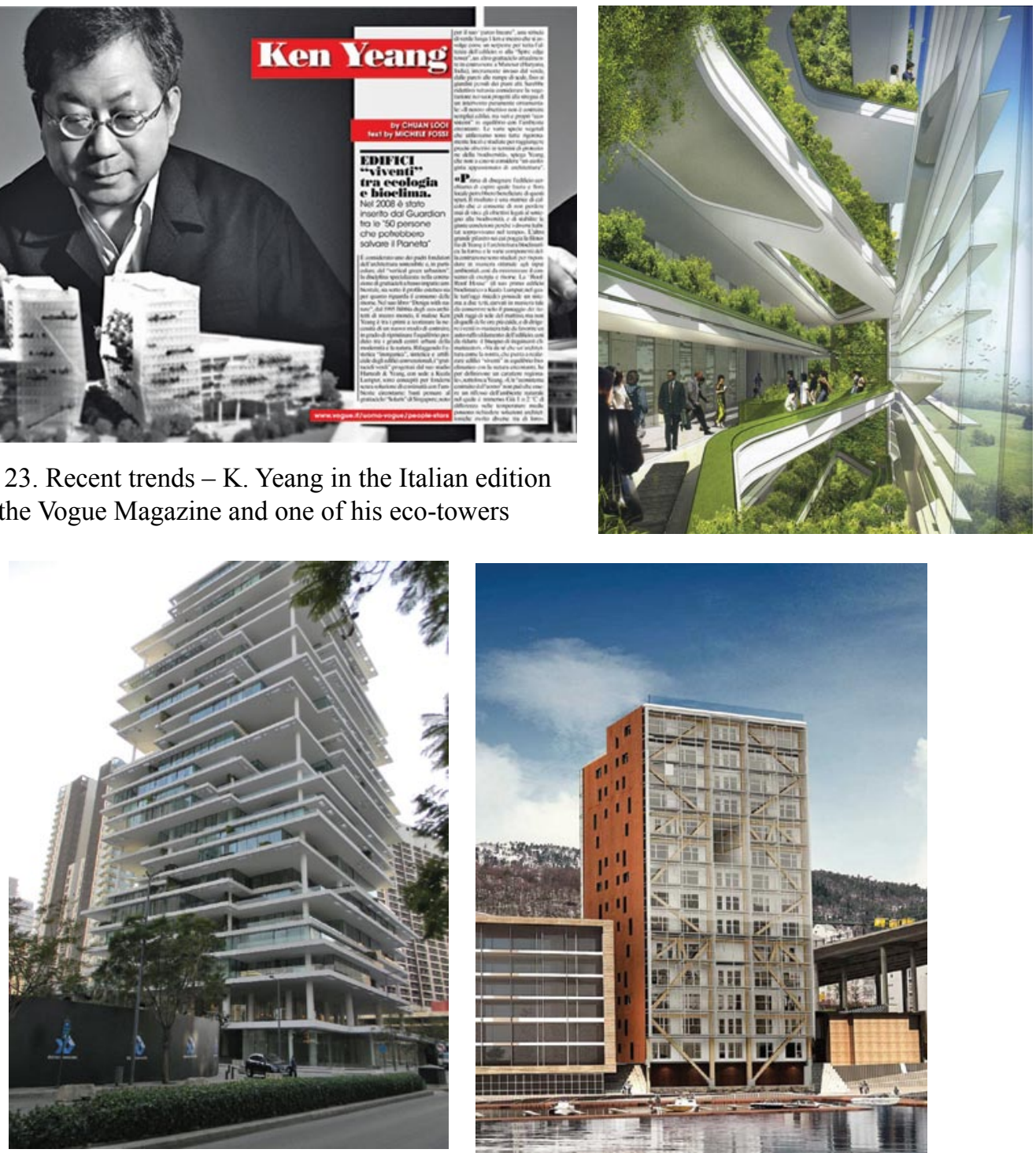

Figure 24. Recent trends (cont') - a Lebanese high-rise (Beirut Terraces by the Swiss Herzog \& de Meuron) and the Bergen Treet (The Tree) project (Norway) 
Another relevant phenomenon in the subject is the ongoing experiments with high-rise buildings made (partially) of timber. Wooden skyscrapers are estimated to be around a quarter of the weight of an equivalent reinforced-concrete building and reduce its carbon footprint by $60-70$ percent. The cross-laminated timber panels used are prefabricated and can therefore reduce construction time. [13] The height contest, however, is going on in this category, too. The previous $32 \mathrm{~m}$ high record holder in Melbourne was beaten in 2015 by a $49 \mathrm{~m}$ high 14 storey timber building in Bergen, Norway. Then in the following year, an 18 storey college building at the University of British Columbia in Vancouver went higher (but the latter combines the timber frame with a reinforced concrete vertical inner core). [16] But its position won't last long as recently there have been plans from Vienna to the US to build higher ones using wood (in the US even the 'Tall Wood Building Prize has been established). Currently, the tallest planned wooden skyscraper is the 70 storey W350 project in Tokyo. [13]

\section{CONCLUSIONS}

The skyscraper city, as it has existed for more than one hundred years, is a tradition by now. However, the skyscraper itself is such a specific building element in the urbanisation process that one is often hesitant to decide how to relate to it. They are celebrated as symbols of a healthy and robust economy on the one hand, and are often condemned for, among others, brutally breaking the skyline of historical cities and for consuming disproportionally much energy on the other. [6] It is also a paradoxical building type: to the first clients of Chicago skyscrapers it was a vehicle to maximise their profits on their plot of land (no frill, sound business proposition), but in the same time the tall building started to 'behave' in ways not keeping with commonsensical business considerations (see their ornaments, fancy shapes and the competitive craze over height). [5]

There are also some myths and frequent ideology driven confusion still among even professionals over the relationship between density and building height. Scientific research, using sophisticated mathematical apparatus, have clearly proved that from the three generic layout patterns the mid-space point block (free-standing tower) delivers the least environmental advantage. They provide real benefits (extra revenues) only for land speculation. [9, 17, 18,] Nevertheless, in the last 60-70 years most successful major cities have effectively turned over their skylines to powerful developers, corporations and their architects. In fact, the aesthetic vision of how our cities will look will always be supplied by professional designers. But it is imperative that the citizens of these cities understand the implications and control the limits of that vision. [5]

With the ever growing number of high-rise buildings, our urban sensory experience has also changed, especially in dense areas where skyscrapers are concentrated as thematic elements. At the dawn of high-rise buildings (and also at present where they are non-thematic elements), if one 'climbed' one of the few towers, he/she could be alone up in the clouds. Now-days, despite that we are, say, on the $40^{\text {th }}$ floor, there are others facing us from the same floor on the opposite side of the street. [6]

Above a certain height, special structural solutions, engineering services and necessary safety measures become so expensive, that there is no pure economic rationale for building them in the super- and the mega-height range (rather considerations of prestige, global competition and place-marketing, respectively, may justify them in the longer term). In spite of all the above discussed, it seems that mankind does not learn much from its previous failures, miscalculations and over-reaching aspirations in this field either and time to time history, however on different levels, apparently repeats itself. 
Nevertheless, a new level of environmental awareness and sensitivity have, without doubt, been looming up in the profession and in some developers. And this might result in some real advances in this subject, too.

\section{REFERENCES}

[1] Müller, W., G. Vogel (1981) dtv-Atlas zur Baukunst, Deutscher Taschenbuch Verlag Gmbh \& Co., München.

[2] JACoBs, J. (1961) The Death and Life of Great American Cities, Random House, New York.

[3] HaLl, P (1990) Cities of Tomorrow, Basil Blackwell, Oxford.

[4] Sudjic, D. (1994) 'The Metropolis, Present and Future', in Polis, September.

[5] Kostof, S. (1991) The City Shaped, The Bulfinch Press, Boston.

[6] Sudjic, D. (2006) The Edifice Complex, How the Rich and Powerful Shape the World, Penguin Books.

[7] National Geographic Society (1992) The Builders, Marvels of Engineering, The Book Division NGS, Washington, D. C.

[8] Weisman, L. K. (1992) Discrimination by Design, A Feminist Critique of the Man-Made Environment, University of Illinois Press, Chicago.

[8b] CTBUH (2019) The Global Tall Building Database, www.skyscapercenter.com

[9] Cuthbert, A. R. (2011) Understanding Cities, Method in Urban Design, Routledge, London.

[10] Lynch, K. (1990) Wasting Away, ed. by M. Southworth, Sierra Club Books, San Francisco.

[11] Craighead, G. (2009) High-Rise Security and Fire Life Safety, Elsevier/Butterworth-Heinemann.

[12] Hall, P. (1998) Cities in Civilization, Pantheon Books, New York.

[13] www.en.wikipedia.org/wiki/Skyscrapers

[14] www.ctbuh.com

[15] MIT Technology Review (2018) Get ready for more and taller skyscrapers, www.technologyreview.com

[16] Hegy D. (2018) Különleges tartószerkezetek, Magasházak (unpublished lecture notes in Hungarian), BME, Budapest.

[17] Martin, L., March, L. EDs. (1972) Urban Space and Structures, The University Press, Cambridge.

[18] March, L., Steadman, P. Eds. (1974) The Geometry of the Environment, MIT Press, Cambridge, Mass.

[19] Cuthbert, A. (1994) 'Opium, Silk and Surveillance, The production of civic space in Hong Kong', in Polis, September.

[20] Bosselmann, P. ex al (1983) Sun, Wind and Comfort, A Study of Open Spaces and Sidewalks of Four Downtown Areas, College of Environmental Design, University of California, Berkeley.

[21] Bentley, I. ET AL (1985) Responsive Environments, The Architectural Press, London.

\section{PHOTO CREDITS}

www.hipflat.com -2

www.pancolina.com $-5 \mathrm{c}$

Elisa Rolle - 7a

www.muemlékvedelem/magazin/fotoalbum - 7b

www.fabsydneyflashbacks.blogspot.com $-7 \mathrm{c}$

Jorge Royan - 8a

www.vizts.com $-8 b$

www.skyscrapernews.com - 9c

www.emporis.com - 10

www.dezeene.com - 13a

Jeffmock - 14a

Papphase $-14 \mathrm{~b}$

www.en.wikipedia.org -20

Author-5b, 9a, 11, 13b-c, 14c, 15, 17, 18b, 22, 24a

(Unmarked illustrations are from the internet under the license of Creative Commons. Every effort was made to identify illustration credits. In case I failed to trace any, I welcome notification and more than happy to make the missing acknowledgement in a following issue of the journal.) 